\title{
The combined effects of light intensity, temperature, and water potential on wall deposition in regulating hypocotyl elongation of Brassica rapa
}

\author{
Hongfei Wang ${ }^{1}$, Qingmao Shang ${ }^{\text {Corresp. } 1}$ \\ ${ }^{1}$ Key Laboratory of Horticultural Crop Biology and Germplasm Innovation (Ministry of Agriculture), Institute of Vegetables and Flowers, Chinese Academy \\ of Agricultural Sciences, Beijing, China \\ Corresponding Author: Qingmao Shang \\ Email address: shanglab211@126.com
}

Hypocotyl elongation is a critical sign of seed germination and seedling growth, and it is regulated by multi environmental factors. Light, temperature, and water potential are the major environmental stimuli, and their regulatory mechanism on hypocotyl growth has been extensively studied at molecular level. However, the converged point in signaling process of light, temperature, and water potential on modulating hypocotyl elongation is still unclear. In the present study, we found cell wall was the co-target of the three environmental factors in regulating hypocotyl elongation by analyzing the extension kinetics of hypocotyl and the changes in hypocotyl cell wall of Brassica rapa under the combined effects of light intensity, temperature, and water potential. The three environmental factors regulated hypocotyl cell elongation both in isolation and in combination. Cell walls thickened, maintained, or thinned depending on growth conditions and developmental stages during hypocotyl elongation. Further analysis revealed that the imbalance in wall deposition and hypocotyl elongation led to dynamic changes in wall thickness. Low light repressed wall deposition by influencing the accumulation of cellulose, hemicellulose, and pectin; high temperature and high water potential had significant effects on pectin accumulation overall. It was concluded that wall deposition was tightly controlled during hypocotyl elongation, and low light, high temperature, and high water potential promoted hypocotyl elongation by repressing wall deposition, especially the deposition of pectin. 


\section{The combined effects of light intensity, temperature,}

2 and water potential on wall deposition in regulating

3 hypocotyl elongation of Brassica rapa

4

5

6

7

8

Hongfei Wang, Qingmao Shang

Key Laboratory of Horticultural Crop Biology and Germplasm Innovation (Ministry of Agriculture), Institute of Vegetables and Flowers, Chinese Academy of Agricultural Sciences, Beijing, China

Corresponding Author: Qingmao Shang No. 12 Zhongguancun South Street, Haidian, Beijing, 100081, China Email address: shangqingmao@caas.cn

\section{Abstract}

Hypocotyl elongation is a critical sign of seed germination and seedling growth, and it is regulated by multi environmental factors. Light, temperature, and water potential are the major environmental stimuli, and their regulatory mechanism on hypocotyl growth has been extensively studied at molecular level. However, the converged point in signaling process of light, temperature, and water potential on modulating hypocotyl elongation is still unclear. In the present study, we found cell wall was the co-target of the three environmental factors in regulating hypocotyl elongation by analyzing the extension kinetics of hypocotyl and the changes in hypocotyl cell wall of Brassica rapa under the combined effects of light intensity, temperature, and water potential. The three environmental factors regulated hypocotyl cell elongation both in isolation and in combination. Cell walls thickened, maintained, or thinned depending on growth conditions and developmental stages during hypocotyl elongation. Further analysis revealed that the imbalance in wall deposition and hypocotyl elongation led to dynamic changes in wall thickness. Low light repressed wall deposition by influencing the accumulation of cellulose, hemicellulose, and pectin; high temperature and high water potential had significant effects on pectin accumulation overall. It was concluded that wall deposition was tightly controlled during hypocotyl elongation, and low light, high temperature, and high water potential promoted hypocotyl elongation by repressing wall deposition, especially the deposition of pectin.

\section{Introduction}

Light, temperature and water potential are the basic environmental conditions for plant survival and have important influences on plant growth and development, including seed germination, root initiation, hypocotyl elongation, leaf growth, flowering and so on (Hersch et al., 2014; 
39 Lorenzo et al., 2016; Patel \& Franklin, 2014; Wilkinson \& Davies, 2010). These environmental 40 factors are often correlated under natural conditions, and their combined effects on seedling growth are often analyzed using hypocotyl elongation, which has been an exemplar model system to study cell expansion (Derbyshire et al., 2007a; Refregier et al., 2004). The synergistic regulation of two environmental factors on hypocotyl elongation, such as "light intensity and temperature" and "light quality and temperature", has been analyzed (Johansson et al., 2014; Kurepin et al., 2010).

Hypocotyl is an appropriate system to study environmental control of plant growth in the early period. The cellular basis of hypocotyl elongation has been extensively studied, indicating that the contribution of cell elongation and division to hypocotyl growth is species- and growth condition-dependent (Gendreau et al., 1997; Raz \& Koornneef, 2001; Scheres et al., 1994). For example, hypocotyl growth exclusively occurs through cell elongation with no contribution from cell division in Arabidopsis thaliana (Boron \& Vissenberg, 2014; Derbyshire et al., 2007b). Cell elongation and division are both observed in elongating hypocotyl of Helianthus annuus (Kutschera \& Niklas, 2013). Hypocotyl extension of Cucumis sativus occurs through cell elongation without division when grown in low light. However, cell elongation and division both contributed to hypocotyl growth under high light (Lopez-Juez et al., 1995).

The extensibility of primary wall plays a critical role in regulating hypocotyl cell elongation induced by environmental factors (Cosgrove, 2016; Pereyra et al., 2010; Xiao et al., 2014). The extensibility of the cell wall often reduces as cell wall polymers are deposited, which is necessary in elongating cells; otherwise, an increase in cell size would be achieved by stretching the existing wall (Derbyshire et al., 2007a; Refregier et al., 2004). To protect the wall from excessive thinning and being ruptured by turgor pressure, cell expansion and wall biosynthesis are coordinately regulated (Ivakov et al., 2017; Voxeur \& Hofte, 2016). The imbalance of cell elongation and wall biosynthesis contributed to dynamic changes in wall thickness (Bischoff et al., 2011; Wu et al., 2005; Xiao et al., 2017). As hypocotyl elongates, cell walls display phases of thickening, maintaining a constant thickness, or becoming thinner, depending on the cell type and developmental stage (Derbyshire et al., 2007a; Refregier et al., 2004). The regulatory effect of single environmental factor on the deposition of cellulose, hemicellulose, and pectin has been extensively studied (Derbyshire et al., 2007a; Le Gall et al., 2015; Sasidharan et al., 2011). However, whether these components are coordinately regulated by multiple environmental factors should be further investigated.

Brassica rapa is an economically important vegetable that is popular worldwide. The hypocotyl of $B$. rapa is particularly sensitive to environmental conditions and can become overelongated, resulting in the potential failure of transplants in the production process (Devlin et al., 1997; Procko et al., 2014). In this paper, the characteristics of hypocotyl growth, dynamic changes in wall thickness, and changes in wall compositions were measured to investigate the co-target of light intensity, temperature, and water potential in regulating hypocotyl elongation. Our hypothesis was that the cell wall was the co-target. Low light, high temperature, and high 
water potential changed wall properties by adjusting its composition and modulated hypocotyl cell growth.

\section{Materials \& Methods}

\section{Plant materials and treatments}

Seeds of B. rapa (cv. CuiBai No. 3) were surface sterilized in 5\% $\mathrm{NaClO}$. The sterilized seeds were sown in vermiculite irrigated with $200 \mathrm{~mL} \mathrm{1/2-strength} \mathrm{Hoagland} \mathrm{solution} \mathrm{after}$ germination, and then cultured at $25^{\circ} \mathrm{C}$ in the dark. At the onset of seedling emergence, the seedlings were irrigated with another $200 \mathrm{~mL}$ 1/2-strength Hoagland solution or a solution with 8\% polyethylene glycol 6000 (PEG-6000; w/v; Sinopharm, Beijing, China), and then cultured in controlled chambers equipped with fluorescent lights (Philips, $28 \mathrm{~W}$, Amsterdam, Netherlands). The light intensity was set to 50 and $250 \mu \mathrm{mol} \mathrm{m} \mathrm{m}^{-2} \mathrm{~s}^{-1}$ (16 h light/ $8 \mathrm{~h}$ dark, Table 1 ), and the R:FR ratios in the different treatments were all 4:1. The spectral outputs were shown in Fig. S1. The temperature was set to $21^{\circ} \mathrm{C}$ and $29^{\circ} \mathrm{C}$, which were kept constant day and night. The water potential of irrigation solutions without or with PEG-6000 was measured by a Psypro water potential system (Wescor, Logan, KY, USA).

\section{Measurements of hypocotyl length, elongation rate, volume and cell length}

The hypocotyl length of B. rapa seedlings was measured in $1 \mathrm{~d}$ intervals using a millimeter scale (accuracy $\pm 0.5 \mathrm{~mm}$ ), and 30 plants were scored in three independent replicates of each treatment. Adjacent measurements were used to calculate the elongation rate. Hypocotyls treated for $8 \mathrm{~d}$ were cut into small segments at the midpoint and fixed in $37 \%$ formaldehyde: acetic acid: ethanol: water $(5: 5: 63: 27)$ for $2 \mathrm{~d}$ at $4{ }^{\circ} \mathrm{C}$. Then, the segments were gradually dehydrated in a series of alcohol solutions, incubated in ethylbenzene/paraffin at $58{ }^{\circ} \mathrm{C}$, and embedded in paraffin. The samples were sliced into $9 \mu \mathrm{m}$ sections and stained using Fast Green dye. The lengths of cells in the epidermis and cortex were measured and photographed using a BX53 light microscope (Olympus, Tokyo, Japan). In total, 15 sections that included 75 cells in three independent replicates were used for cell length determination. Cell number of epidermis and cortex was calculated from the hypocotyl length divided by the cell length.

\section{Measurement of cell wall thickness}

After the seedlings were treated for $0,2,5$, or $8 \mathrm{~d}$, they were cut into $2 \mathrm{~mm}$ segments at the midpoint and fixed in 3\% glutaraldehyde buffer $(\mathrm{v} / \mathrm{v} ; \mathrm{pH} 7.3)$ in the dark. The segments were rinsed with phosphatic buffer solution $(0.1 \mathrm{M}, \mathrm{pH} 7.2)$ and post-fixed in $1 \% \mathrm{OsO}_{4}$, which was followed by washes with phosphatic buffer solution. Then, the samples were gradually dehydrated in a series of alcohol solutions, incubated in acetone/resin at $35^{\circ} \mathrm{C}$ and embedded in resin at $40{ }^{\circ} \mathrm{C}$. The samples were sliced into ultrathin transverse sections of $\sim 90 \mathrm{~nm}$ using a glass knife on a Reichert ultramicrotome (Leica, Milton Keynes, UK). The slices were collected on 200-mesh copper grids and stained with $2 \%(\mathrm{w} / \mathrm{v})$ uranyl acetate for $15 \mathrm{~min}$ and $1 \%(\mathrm{w} / \mathrm{v})$ lead citrate for $10 \mathrm{~min}$. Then, the slices were washed with water and air-dried in petri dishes. Cell walls were observed using a Jeol JEM-1230 transmission electron microscope (JEOL, Tokyo, 
116 Japan) and photographed. Envisioning the hypocotyls as cylinders, the volume $=\pi *$ (radius of

117 hypocotyl at midpoint) ${ }^{2} *$ hypocotyl length. The wall volume was calculated from sections at the

118 midpoint of the hypocotyl, and the transverse wall was not included (Fig. S2A), as previously

119 described (Derbyshire et al., 2007a). The wall volume of the outer epidermal wall (OE) was

120 calculated by multiplying the perimeter of the hypocotyl at the midpoint by the OE thickness and

121 by the hypocotyl length. The volume of the inner epidermal wall (IE) was calculated by

122 multiplying the perimeter of the IE by the number of epidermis, by the thickness of the IE, and

123 by the hypocotyl length. The wall volume of the cortical wall (CO) adjacent to the OE was

124 considered the $\mathrm{CO}$ volume and calculated by multiplying the perimeter of the $\mathrm{CO}$ by its number,

125 by the thickness of the CO, and by the hypocotyl length (Fig. S2B). The perimeter of the IE $=2 \pi$

$126 *$ radius of epidermis cell $*$ the cell number - the perimeter of the hypocotyl at the midpoint. The

127 number of epidermal cell $=2 \pi *$ (radius of hypocotyl - the radius of epidermal cell)/diameter of

128 the epidermal cells. The number of cortical cell $=2 \pi *$ (the radius of hypocotyl - the diameter of

129 epidermal cell - the radius of cortical cell adjacent to the epidermal cell)/diameter of the cortical

130 cells. The data used to calculate the index were from three independent replicates that included 6

131 hypocotyls and 60 cells. The fold change in hypocotyl volume induced by low light $=$

$132\left(\mathrm{~L}_{1} \mathrm{~T}_{1} \mathrm{~W}_{1} / \mathrm{L}_{\mathrm{h}} \mathrm{T}_{1} \mathrm{~W}_{1}+\mathrm{L}_{1} \mathrm{~T}_{1} \mathrm{~W}_{\mathrm{h}} / \mathrm{L}_{\mathrm{h}} \mathrm{T}_{1} \mathrm{~W}_{\mathrm{h}}+\mathrm{L}_{\mathrm{l}} \mathrm{T}_{\mathrm{h}} \mathrm{W}_{1} / \mathrm{L}_{\mathrm{h}} \mathrm{T}_{\mathrm{h}} \mathrm{W}_{1}+\mathrm{L}_{\mathrm{l}} \mathrm{T}_{\mathrm{h}} \mathrm{W}_{\mathrm{h}} / \mathrm{L}_{\mathrm{h}} \mathrm{T}_{\mathrm{h}} \mathrm{W}_{\mathrm{h}}\right) / 4$; the fold change in

133 hypocotyl volume induced by high temperature $=\left(\mathrm{L}_{\mathrm{h}} \mathrm{T}_{\mathrm{h}} \mathrm{W}_{\mathrm{l}} / \mathrm{L}_{\mathrm{h}} \mathrm{T}_{1} \mathrm{~W}_{1}+\mathrm{L}_{\mathrm{h}} \mathrm{T}_{\mathrm{h}} \mathrm{W}_{\mathrm{h}} / \mathrm{L}_{\mathrm{h}} \mathrm{T}_{1} \mathrm{~W}_{\mathrm{h}}+\right.$

$\left.134 \mathrm{~L}_{1} \mathrm{~T}_{\mathrm{h}} \mathrm{W}_{1} / \mathrm{L}_{1} \mathrm{~T}_{1} \mathrm{~W}_{1}+\mathrm{L}_{1} \mathrm{~T}_{\mathrm{h}} \mathrm{W}_{\mathrm{h}} / \mathrm{L}_{1} \mathrm{~T}_{1} \mathrm{~W}_{\mathrm{h}}\right) / 4$; the fold change in hypocotyl volume induced by high water

135 potential $=\left(\mathrm{L}_{\mathrm{h}} \mathrm{T}_{1} \mathrm{~W}_{\mathrm{h}} / \mathrm{L}_{\mathrm{h}} \mathrm{T}_{1} \mathrm{~W}_{1}+\mathrm{L}_{\mathrm{h}} \mathrm{T}_{\mathrm{h}} \mathrm{W}_{\mathrm{h}} / \mathrm{L}_{\mathrm{h}} \mathrm{T}_{\mathrm{h}} \mathrm{W}_{1}+\mathrm{L}_{1} \mathrm{~T}_{1} \mathrm{~W}_{\mathrm{h}} / \mathrm{L}_{\mathrm{l}} \mathrm{T}_{1} \mathrm{~W}_{1}+\mathrm{L}_{\mathrm{l}} \mathrm{T}_{\mathrm{h}} \mathrm{W}_{\mathrm{h}} / \mathrm{L}_{1} \mathrm{~T}_{\mathrm{h}} \mathrm{W}_{1}\right) / 4$.

\section{Determination of hypocotyl cell wall masses and content in components}

137 The cell wall mass of hypocotyls was determined according to the previous method (Zhong \&

138 Lauchli, 1993). Approximately 40 hypocotyl segments treated for $8 \mathrm{~d}$ were harvested, weighed,

139 and frozen in liquid nitrogen. The frozen samples were homogenized to powder and washed into

140 centrifuge tubes using $1 \mathrm{~mL}$ ice-cold $75 \%$ ethanol. The tubes were kept in ice for 20 min without

141 disturbing, followed by centrifugation for $10 \mathrm{~min}$ at $10000 \times \mathrm{g}$. The pellets were sequentially

142 washed using ice-cold acetone, a mixture of methanol and chloroform (1:1, v/v), and methanol.

143 The pellets were considered as cell wall preparations and weighed after lyophilization.

144 The cell wall preparations were fractionated into four fractions, including pectin,

145 hemicellulose 1 (HC1), hemicellulose 2 (HC2), and cellulose (Iraki et al., 1989; Labavitch \&

146 Ray, 1974). The freeze-dried pellets were suspended in $2 \mathrm{~mL} 0.5 \%$ ammonium oxalate buffer

147 containing $0.1 \% \mathrm{NaBH}_{4}(\mathrm{pH} 4.0)$ in a boiling water bath for pectin extraction. Then, the pellets

148 were subjected to another extraction with $5 \mathrm{~mL} 4 \% \mathrm{KOH}$ containing $0.1 \% \mathrm{NaBH}_{4}$ at room

149 temperature, and the extraction solutions were $\mathrm{HC} 1$ fractions. The protocol for the HC2

150 extraction was similar to that for $\mathrm{HC} 1$ extraction, but $24 \% \mathrm{KOH}$ was used. Before determination,

$151 \mathrm{HC} 1$ and $\mathrm{HC} 2$ solutions were neutralized with glacial acetic acid. The residuals in the centrifuge

152 tubes were regarded as cellulose and freeze-dried before weighing. The pectin content was

153 determined by carbazole colorimetry as previously described (Stark, 1950). Hemicellulose

154 content was determined by anthrone assay (Updegraff, 1969). The decrease in wall component

155 content induced by low light $=\left(1\right.$ - average $\left(\mathrm{L}_{1} \mathrm{~T}_{1} \mathrm{~W}_{1} / \mathrm{L}_{\mathrm{h}} \mathrm{T}_{1} \mathrm{~W}_{1}+\mathrm{L}_{l} \mathrm{~T}_{1} \mathrm{~W}_{\mathrm{h}} / \mathrm{L}_{\mathrm{h}} \mathrm{T}_{1} \mathrm{~W}_{\mathrm{h}}+\mathrm{L}_{\mathrm{l}} \mathrm{T}_{\mathrm{h}} \mathrm{W}_{1} / \mathrm{L}_{\mathrm{h}} \mathrm{T}_{\mathrm{h}} \mathrm{W}_{1}\right.$ 
$\left.\left.156+\mathrm{L}_{1} \mathrm{~T}_{\mathrm{h}} \mathrm{W}_{\mathrm{h}} / \mathrm{L}_{\mathrm{h}} \mathrm{T}_{\mathrm{h}} \mathrm{W}_{\mathrm{h}}\right)\right) * 100 \%$; the decrease in wall component content induced by high

157 temperature $=\left(1-\right.$ average $\left(\mathrm{L}_{\mathrm{h}} \mathrm{T}_{\mathrm{h}} \mathrm{W}_{1} / \mathrm{L}_{\mathrm{h}} \mathrm{T}_{1} \mathrm{~W}_{1}+\mathrm{L}_{\mathrm{h}} \mathrm{T}_{\mathrm{h}} \mathrm{W}_{\mathrm{h}} / \mathrm{L}_{\mathrm{h}} \mathrm{T}_{1} \mathrm{~W}_{\mathrm{h}}+\mathrm{L}_{1} \mathrm{~T}_{\mathrm{h}} \mathrm{W}_{1} / \mathrm{L}_{1} \mathrm{~T}_{1} \mathrm{~W}_{1}+\right.$

$\left.\left.158 \mathrm{~L}_{1} \mathrm{~T}_{\mathrm{h}} \mathrm{W}_{\mathrm{h}} / \mathrm{L}_{1} \mathrm{~T}_{1} \mathrm{~W}_{\mathrm{h}}\right)\right) * 100 \%$; the decrease in wall component content induced by high water

159 potential $=\left(1-\right.$ average $\left.\left(\mathrm{L}_{\mathrm{h}} \mathrm{T}_{1} \mathrm{~W}_{\mathrm{h}} / \mathrm{L}_{\mathrm{h}} \mathrm{T}_{1} \mathrm{~W}_{1}+\mathrm{L}_{\mathrm{h}} \mathrm{T}_{\mathrm{h}} \mathrm{W}_{\mathrm{h}} / \mathrm{L}_{\mathrm{h}} \mathrm{T}_{\mathrm{h}} \mathrm{W}_{1}+\mathrm{L}_{1} \mathrm{~T}_{1} \mathrm{~W}_{\mathrm{h}} / \mathrm{L}_{1} \mathrm{~T}_{1} \mathrm{~W}_{1}+\mathrm{L}_{1} \mathrm{~T}_{\mathrm{h}} \mathrm{W}_{\mathrm{h}} / \mathrm{L}_{1} \mathrm{~T}_{\mathrm{h}} \mathrm{W}_{1}\right)\right)$

$160 * 100 \%$.

161 Gene expression analysis by quantitative RT-PCR

162 Total RNA was extracted from hypocotyls using TRIzol reagent (Invitrogen, Gaithersburg, MD, 163 USA) according to the manufacturer's instruction. The first-strand cDNA was synthesized using 164 a reverse transcription system (Promega, Madison, WI, USA), and real-time PCR was carried out 165 with a SYBR Green Supermix (Transgene, Beijing, China) on a LightCycler® 96 real-time PCR 166 system (Roche, Basel, Switzerland). The reactions were performed with three replicates using 167 GAPDH (Bra016729) as the reference gene (Procko et al., 2014; Qi et al., 2010), and the relative 168 expression levels of the target genes were calculated using the $2^{-\Delta \Delta C t}$ method (Schmittgen \& 169 Livak, 2008). The primers used to quantify the gene expression levels were listed in Table S1.

\section{Statistical analysis}

171 The values presented in pictures and tables represent the mean (three replicates) \pm standard error 172 (SE). Significance was analyzed using SAS 9.2.0 software with Duncan's multiple range test $(P$ $173<0.05)$.

174 Results

\section{Hypocotyl elongation kinetics}

176 Hypocotyl elongation kinetics of $B$. rapa seedlings were established in eight treatments that were used to detect the combined effects of light intensity, temperature, and water potential on hypocotyl growth. Hypocotyl length was measured over a period of $8 \mathrm{~d}$ after treatments, and the final length showed a high degree of variability in the eight treatments: high light $\times$ low temperature $\times$ low water potential $\left(\mathrm{L}_{\mathrm{h}} \mathrm{T}_{1} \mathrm{~W}_{\mathrm{l}}\right)$, high light $\times$ low temperature $\times$ high water potential $\left(\mathrm{L}_{\mathrm{h}} \mathrm{T}_{1} \mathrm{~W}_{\mathrm{h}}\right)$, high light $\times$ high temperature $\times$ low water potential $\left(\mathrm{L}_{\mathrm{h}} \mathrm{T}_{\mathrm{h}} \mathrm{W}_{\mathrm{l}}\right)$, high light $\times$ high temperature $\times$ high water potential $\left(\mathrm{L}_{\mathrm{h}} \mathrm{T}_{\mathrm{h}} \mathrm{W}_{\mathrm{h}}\right)$, low light $\times$ low temperature $\times$ low water potential $\left(\mathrm{L}_{1} \mathrm{~T}_{1} \mathrm{~W}_{1}\right)$, low light $\times$ low temperature $\times$ high water potential $\left(\mathrm{L}_{1} \mathrm{~T}_{1} \mathrm{~W}_{\mathrm{h}}\right)$, low light $\times$ high temperature $\times$ low water potential $\left(\mathrm{L}_{1} \mathrm{~T}_{\mathrm{h}} \mathrm{W}_{1}\right)$, and low light $\times$ high temperature $\times$ high water potential $\left(\mathrm{L}_{1} \mathrm{~T}_{\mathrm{h}} \mathrm{W}_{\mathrm{h}}\right)\left(\right.$ Fig. 1A-H). According to binary comparisons $\left(\mathrm{L}_{1} \mathrm{~T}_{1} \mathrm{~W}_{1}\right.$ vs $\mathrm{L}_{\mathrm{h}} \mathrm{T}_{1} \mathrm{~W}_{\mathrm{l}}, \mathrm{L}_{1} \mathrm{~T}_{1} \mathrm{~W}_{\mathrm{h}}$ vs $\mathrm{L}_{h} \mathrm{~T}_{1} \mathrm{~W}_{\mathrm{h}}, \mathrm{L}_{1} \mathrm{~T}_{\mathrm{h}} \mathrm{W}_{1}$ vs $\mathrm{L}_{\mathrm{h}} \mathrm{T}_{\mathrm{h}} \mathrm{W}_{1}$, and $\mathrm{L}_{1} \mathrm{~T}_{\mathrm{h}} \mathrm{W}_{\mathrm{h}}$ vs $\mathrm{L}_{\mathrm{h}} \mathrm{T}_{\mathrm{h}} \mathrm{W}_{\mathrm{h}}$ ), the increase in hypocotyl length induced by low light was $1.17,1.10,1.33$, and $1.99 \mathrm{~cm}$, respectively. The effect of light intensity on hypocotyl growth was affected by temperature and water potential. The increase in hypocotyl length induced by high temperature $\left(\mathrm{L}_{h} \mathrm{~T}_{\mathrm{h}} \mathrm{W}_{1}\right.$ vs $\mathrm{L}_{\mathrm{h}} \mathrm{T}_{1} \mathrm{~W}_{1}, \mathrm{~L}_{\mathrm{h}} \mathrm{T}_{\mathrm{h}} \mathrm{W}_{\mathrm{h}}$ vs $\mathrm{L}_{\mathrm{h}} \mathrm{T}_{1} \mathrm{~W}_{\mathrm{h}}, \mathrm{L}_{1} \mathrm{~T}_{\mathrm{h}} \mathrm{W}_{1}$ vs $\mathrm{L}_{1} \mathrm{~T}_{1} \mathrm{~W}_{\mathrm{l}}$, and $\mathrm{L}_{1} \mathrm{~T}_{\mathrm{h}} \mathrm{W}_{\mathrm{h}} \mathrm{vs}_{\mathrm{l}} \mathrm{T}_{1} \mathrm{~W}_{\mathrm{h}}$ ) were $0.35,0.30,0.51$, and $1.19 \mathrm{~cm}$, respectively. The promotion of high temperature on hypocotyl growth was highly dependent on light intensity and water potential. The hypocotyl length increased by $0.26,0.21,0.19$, and $0.86 \mathrm{~cm}$ when grown under the high water potential conditions $\left(\mathrm{L}_{h} \mathrm{~T}_{1} \mathrm{~W}_{h}\right.$ vs $\mathrm{L}_{h} \mathrm{~T}_{1} \mathrm{~W}_{1}, \mathrm{~L}_{\mathrm{h}} \mathrm{T}_{\mathrm{h}} \mathrm{W}_{\mathrm{h}}$ vs $\mathrm{L}_{h} \mathrm{~T}_{h} \mathrm{~W}_{1}, \mathrm{~L}_{1} \mathrm{~T}_{1} \mathrm{~W}_{\mathrm{h}}$ vs $\mathrm{L}_{1} \mathrm{~T}_{1} \mathrm{~W}_{\mathrm{l}}$, and 
194

195

196

197

198

199

200

201

202

203

204

205

206

207

208

209

210

211

212

213

214

215

216

217

218

219

220

221

222

223

224

225

226

227

228

229

230

231

232

233

$\mathrm{L}_{1} \mathrm{~T}_{\mathrm{h}} \mathrm{W}_{\mathrm{h}}$ vs $\left.\mathrm{L}_{1} \mathrm{~T}_{\mathrm{h}} \mathrm{W}_{1}\right)$. The influence of high water potential was tightly dependent on light intensity and temperature. The results above indicated that light intensity, temperature, and water potential regulated hypocotyl elongation independently and in coordination.

The hypocotyls of $B$. rapa seedlings grown under the eight conditions above were analyzed in further at equivalent developmental stages, including stage I at the onset of seedling emergence, stage II at $50 \%$ of the maximal increase in hypocotyl length, stage III at $90 \%$ of the maximal increase in hypocotyl length, and stage IV at the final hypocotyl length, which were estimated from the elongation curves and indicated by the arrows in Fig. 1B. These stages were set at 0,2, 5 , and $8 \mathrm{~d}$ after treatments, and the general morphology of the seedlings at the four stages above were shown in Fig. 1A-H and Fig. S3.

\section{Cell elongation primarily contributed to hypocotyl extension}

Next, the changes in cell length and the number of cell files in the longitudinal direction accompanying hypocotyl elongation were examined. The structure of the B. rapa hypocotyl was relatively simple, mainly consisting of epidermis, cortex, endodermis, and pericycle (Fig. S4). Epidermis is the outermost cell that determines the elongation rates of organs (Kutschera \& Niklas, 2007). Cortical cells are relatively abundant in the B. rapa hypocotyl. Therefore, the epidermis and cortex were selected for further analysis. The length of epidermal and cortical cells was measured using paraffin sections at the midpoint of the hypocotyl (Fig. 2), and cell numbers in the longitudinal direction were calculated according to cell and hypocotyl length (Table 2). The midpoint was selected to measure the cell length because hypocotyl elongation after seedling germination was mainly caused by the middle and apical segments, and the cell length at the midpoint was similar to the average length of hypocotyl cells (Gendreau et al., 1997; Procko et al., 2014; Paque et al., 2014). In addition, light intensity, temperature, and water potential regulated hypocotyl elongation mainly through affecting the growth of middle and apical segments (Fig. S5). Under the combined effects of light intensity, temperature, and water potential, the difference in cell lengths of epidermal and cortical cells reached a significant level among the eight treatments $(P<0.05$; Duncan's multiple range test). According to binary comparisons (all the binary comparison below were done in the same order as the corresponding comparisons in the part of Hypocotyl elongation kinetics), the lengths of epidermal cells increased by $31.91,76.30,21.58$, and $27.31 \mu \mathrm{m}$ under low light, and the corresponding increases in cortical cell length were $64.65,79.73,49.51,55.91 \mu \mathrm{m}$. High temperature promoted epidermal cell elongating by $10.27,12.60,20.60$, and $61.59 \mu \mathrm{m}$, and cortical cell elongating by 14.75 , $15.83,29.89$, and $39.64 \mu \mathrm{m}$. Under the influence of high water potential, epidermal cells elongated by $6.57,8.90,12.30$, and $53.27 \mu \mathrm{m}$, and cortical cells elongated by $15.24,16.31$, 21.63 , and $31.40 \mu \mathrm{m}$. Further analysis indicated that the influence of light intensity, temperature, and water potential on hypocotyl growth were all significant $(P<0.05$; Duncan's multiple range test). In addition, the number of the epidermal and cortical cells on the longitudinal axis was calculated. About 50, 20, and 20 layers were added in epidermis responding to low light, high temperature, and high water potential. The corresponding variation in the number of cortical cell layers was approximately 20,20, and 10 . The influence of light intensity on epidermal cell layers

Peer) reviewing PDF | (2019:08:40056:3:0:NEW 27 Mar 2020) 
234 reached a significant level, but not on the number of cortical cells $(P<0.05$; Duncan's multiple 235 range test). Temperature and water potential had no significant effects on the number of 236 epidermal and cortical cell. To elucidate the contribution of cell division to hypocotyl elongation 237 induced by low light, high temperature, and high water potential in further, the relative 238 expression level of the marker genes: $C D C A 3 ; 2, C D C B 1 ; 1$ and $C D K A ; 1$, was investigated 239 (Dewitte and Murray, 2003; Joubès et al., 2000). And only light intensity have significant 240 influences on the express level of genes involved in cell division $(P<0.05$; Duncan's multiple 241 range test) (Fig. S6). The results above implied that cell elongation primarily contributed to 242 hypocotyl elongation in B. rapa induced by high temperature and high water potential. Cell 243 division and elongation both contributed to hypocotyl elongation under the influence of low light.

\section{Dynamic changes in cell wall thickness}

245 TEM was used to observe the cell wall of the epidermis and cortex at the four developmental stages indicated in Fig. 1. Typical micrographs of the OE, IE, CO in the hypocotyl at the final length (stage IV) were shown in Fig. 3.

At the onset of seedling emergence (stage I), the OE, IE, and CO were approximately 1.19,

250

251

252

253

254

255

256

257

258

259

260

261

262

263

264

265

266

267

268

269

270

271

272

273 0.50 , and $0.36 \mu \mathrm{m}$, respectively (Fig. 4), and the thickness of the OE, IE, and CO thickened by $24 \%, 14 \%$ and $5 \%$ on average, following seedling emergence (stage II). However, the OE thickened by $13 \%$, and the IE and CO thinned by $5 \%$ and $25 \%$ at stage III, respectively. At stage IV, the OE and IE thickened by $43 \%$ and $16 \%$ on average, respectively. But the CO thinned by $4 \%$, compared with the thickness at stage I.

According to binary comparisons, light intensity had significant effects on wall thickness at all three stages (Fig. 4, Figs. S7-S9 and Table S2) $(P<0.05$; Duncan's multiple range test). The OE thinned by $21 \%, 38 \%$, and $19 \%$ on average under the effect of low light at stage II, stage III, and stage IV, respectively. Similar responses of the IE and CO were observed: the IE thinned by $26 \%, 32 \%$, and $35 \%$, and the CO thinned by $25 \%, 29 \%$, and $35 \%$ at the three stages. Compared with the hypocotyls grown at low temperature, those grown at high temperature acquired thinner cell walls. The thickness of the OE decreased by $12 \%, 21 \%$, and $16 \%$ at stage II, stage III, and stage IV, respectively. And IE thinned by $18 \%, 18 \%$, and $9 \%$ at stage II, stage III, and stage IV, respectively; the CO thinned by $15 \%, 22 \%$, and $14 \%$ at stage II, stage III, and stage IV, respectively. Water potential also had a significant effect on the dynamic changes in wall thickness (Table S2; $P<0.05$; Duncan's multiple range test), and the $\mathrm{OE}$ thinned by $11 \%, 11 \%$, and $14 \%$ at stage II, stage III, and stage IV under the influence of high water potential, respectively. The thinning of inner walls was more dramatic, with a $17 \%, 20 \%$, and $18 \%$ decrease in IE and a $14 \%, 17 \%$, and $18 \%$ decrease in CO.

As the hypocotyl elongated, the thickness of the $\mathrm{OE}$ changed with the trend of thickeningmaintaining-thickening under the conditions of $\mathrm{L}_{h} \mathrm{~T}_{1} \mathrm{~W}_{1}, \mathrm{~L}_{h} \mathrm{~T}_{1} \mathrm{~W}_{h}, \mathrm{~L}_{h} \mathrm{~T}_{h} \mathrm{~W}_{1}$, and $\mathrm{L}_{h} \mathrm{~T}_{h} \mathrm{~W}_{h}$, and it changed with the trend of thickening-thinning-thickening under the conditions of $\mathrm{L}_{1} \mathrm{~T}_{1} \mathrm{~W}_{1}, \mathrm{~L}_{1} \mathrm{~T}_{1} \mathrm{~W}_{\mathrm{h}}$, $\mathrm{L}_{1} \mathrm{~T}_{\mathrm{h}} \mathrm{W}_{1}$, and $\mathrm{L}_{1} \mathrm{~T}_{\mathrm{h}} \mathrm{W}_{\mathrm{h}}$. The thickness of the IE and $\mathrm{CO}$ changed by thickening-thinning-thickening under $\mathrm{L}_{h} \mathrm{~T}_{1} \mathrm{~W}_{l}, \mathrm{~L}_{h} \mathrm{~T}_{1} \mathrm{~W}_{\mathrm{h}}, \mathrm{L}_{\mathrm{h}} \mathrm{T}_{\mathrm{h}} \mathrm{W}_{\mathrm{l}}, \mathrm{L}_{\mathrm{h}} \mathrm{T}_{\mathrm{h}} \mathrm{W}_{\mathrm{h}}$, and $\mathrm{L}_{\mathrm{l}} \mathrm{T}_{1} \mathrm{~W}_{1}$ and changed by thinning-thinningthickening under $\mathrm{L}_{l} \mathrm{~T}_{1} \mathrm{~W}_{\mathrm{h}}, \mathrm{L}_{1} \mathrm{~T}_{\mathrm{h}} \mathrm{W}_{1}$, and $\mathrm{L}_{1} \mathrm{~T}_{\mathrm{h}} \mathrm{W}_{\mathrm{h}}$. Low light repressed $\mathrm{OE}$, IE, and CO thickening at 
274 stage II, stage III, and stage IV. High temperature and high water potential had similar effects on

275 wall thickness, but their effects were weaker than those of light intensity.

276 Cell wall was the co-target of the three environmental factors in regulating hypocotyl 277 elongation

278 The amount of wall deposition had important impacts on wall thickness, which was negatively

279 related to wall extension (Derbyshire et al., 2007a). We measured the wall mass and component

280 contents in hypocotyls under the coordinated regulation of light intensity, temperature, and water

281 potential (Table 3). The variation in wall mass was consistent with that of wall volume, which

282 was calculated based on the wall thickness in Fig. 4, indicating that TEM could be used to

283 measure wall thickness.

284 To further analyze the effects of light intensity, temperature, and water potential on wall

285 deposition, the content of wall components was measured. The analysis of variance (ANOVA)

286 about cellulose, hemicellulose, and pectin indicated that pectin was the co-target of

287 environmental factors in regulating hypocotyl cell elongation (Table S3; $P<0.05$; Duncan's

288 multiple range test). Low light repressed cellulose, hemi-cellulose, and pectin deposition

289 significantly (Table S3; $P<0.05$; Duncan's multiple range test), and their contents decreased by

$29043 \%, 41 \%$, and $43 \%$ on average, respectively. High temperature had effects on deposition of

291 cellulose, hemicellulose, and pectin, inducing their contents decreased by $13 \%, 9 \%$, and $15 \%$,

292 respectively. Further analysis indicated that the effect on the deposition of pectin reached

293 significant level on the whole (Table S3; $P<0.05$; Duncan's multiple range test). And the effect

294 on hemicellulose reached significant level only under specific environmental factors $\left(\mathrm{L}_{1} \mathrm{~T}_{1} \mathrm{~W}_{1} \mathrm{vs}\right.$

$295 \mathrm{~L}_{\mathrm{l}} \mathrm{T}_{\mathrm{h}} \mathrm{W}_{\mathrm{l}}, \mathrm{L}_{\mathrm{l}} \mathrm{T}_{1} \mathrm{~W}_{\mathrm{h}}$ vs $\mathrm{L}_{\mathrm{l}} \mathrm{T}_{\mathrm{h}} \mathrm{W}_{\mathrm{h}}$; Table 3; $P<0.05$; Duncan's multiple range test). High water

296 potential inhibited wall deposition with decreases of $11 \%, 13 \%$, and $15 \%$ in cellulose,

297 hemicellulose, and pectin on average. Its effect on the deposition of cellulose reached significant

298 level under specific conditions $\left(\mathrm{L}_{1} \mathrm{~T}_{1} \mathrm{~W}_{1}\right.$ vs $\mathrm{L}_{1} \mathrm{~T}_{1} \mathrm{~W}_{\mathrm{h}}, \mathrm{L}_{1} \mathrm{~T}_{\mathrm{h}} \mathrm{W}_{1}$ vs $\left.\mathrm{L}_{1} \mathrm{~T}_{\mathrm{h}} \mathrm{W}_{\mathrm{h}}\right)$ (Table $3 ; P<0.05$;

299 Duncan's multiple range test). Although its effect on pectin accumulation was significant on the

300 overall level, it did not reach a significant level under specific conditions, such as $\mathrm{L}_{1} \mathrm{~T}_{1} \mathrm{~W}_{1}$ vs

$301 \mathrm{~L}_{\mathrm{l}} \mathrm{T}_{\mathrm{l}} \mathrm{W}_{\mathrm{h}}$ (Table 3; $P<0.05$; Duncan's multiple range test).

302 Hypocotyl cell elongation induced by low light, high temperature, and high water potential

303 was mainly affected by wall extensibility, which was under the control of wall deposition and

304 wall-modifying proteins, such as expansins (EXPA) and xyloglucan

305 endotransglucosylase/hydrolase (XET/XTH). To investigate the change in wall extensibility as

306 hypocotyl cells elongated, the expression levels of genes involved in cell wall biosynthesis and

307 modification were investigated (Fig. S10-S11). Light intensity had a significant influence on the

308 biosynthesis of wall components, and some genes involved in cellulose, hemicellulose, and

309 pectin biosynthesis were upregulated by low light, such as CesA6, CSLC4, and XXT5 (Table S4;

$310 P<0.05$; Duncan's multiple range test). Comparing with $\mathrm{L}_{\mathrm{h}} \mathrm{T}_{1} \mathrm{~W}_{\mathrm{h}}, \mathrm{L}_{\mathrm{h}} \mathrm{T}_{\mathrm{h}} \mathrm{W}_{\mathrm{l}}$, and $\mathrm{L}_{\mathrm{h}} \mathrm{T}_{\mathrm{h}} \mathrm{W}_{\mathrm{h}}$, the

311 expression level of gene involved in pectin biosynthesis, GAUT7, was higher in the condition of

$312 \mathrm{~L}_{\mathrm{l}} \mathrm{T}_{1} \mathrm{~W}_{\mathrm{h}}, \mathrm{L}_{\mathrm{l}} \mathrm{T}_{\mathrm{h}} \mathrm{W}_{\mathrm{l}}$, and $\mathrm{L}_{\mathrm{l}} \mathrm{T}_{\mathrm{h}} \mathrm{W}_{\mathrm{h}}$. Temperature had a significant effect on the expression level of

313 genes involved in the biosynthesis of hemicellulose and pectin (Table S4; $P<0.05$; Duncan's 
314 multiple range test). Under the influence of high temperature, the expression level of $X X T 1$, $315 X X T 5, M U R 3, G A U T 7$, and RGX2 improved overall, and the expression level of CSLC6 reduced.

316 In addition, the expression level of the pectin biosynthesis gene, GAUT1, improved significantly 317 under $\mathrm{L}_{h} \mathrm{~T}_{1} \mathrm{~W}_{1}$ and $\mathrm{L}_{\mathrm{h}} \mathrm{T}_{1} \mathrm{~W}_{\mathrm{h}}$ compared with that under $\mathrm{L}_{\mathrm{h}} \mathrm{T}_{\mathrm{h}} \mathrm{W}_{\mathrm{l}}$, and $\mathrm{L}_{\mathrm{h}} \mathrm{T}_{\mathrm{h}} \mathrm{W}_{\mathrm{h}}$. Water potential had 318 an effect on pectin synthesis, and the expression levels of GAUT7 and RGXT2 were upregulated 319 by high water potential. The expression level of GAUT7 and RGXT2 was higher under $\mathrm{L}_{\mathrm{h}} \mathrm{T}_{1} \mathrm{~W}_{\mathrm{h}}$, $320 \mathrm{~L}_{\mathrm{h}} \mathrm{T}_{\mathrm{h}} \mathrm{W}_{\mathrm{h}}, \mathrm{L}_{\mathrm{l}} \mathrm{T}_{1} \mathrm{~W}_{\mathrm{h}}$, and $\mathrm{L}_{1} \mathrm{~T}_{\mathrm{h}} \mathrm{W}_{\mathrm{h}}$ than that under $\mathrm{L}_{\mathrm{h}} \mathrm{T}_{1} \mathrm{~W}_{\mathrm{l}}, \mathrm{L}_{\mathrm{h}} \mathrm{T}_{\mathrm{h}} \mathrm{W}_{\mathrm{l}}, \mathrm{L}_{\mathrm{T}} \mathrm{T}_{1} \mathrm{~W}_{\mathrm{l}}$, and $\mathrm{L}_{\mathrm{l}} \mathrm{T}_{\mathrm{h}} \mathrm{W}_{\mathrm{l}}$, respectively. 321 In summary, the biosynthesis of pectin was co-regulated by light intensity, temperature, and 322 water potential. According to Paque et al. (2014), five XTHs and one EXPA genes were selected to investigate their expression level under the combined effects of light intensity, temperature,

324

325

326

327

328

329

330

331

332

333

334

335

336

337

338

339

340

341

342

343

344

345

346

347

348

349

350 and water potential (Fig. S11). Light intensity had a significant effect on the six genes (Table S4), and the expression of XTH17, XTH22, XTH31, XTH33, and EXPA20 was induced by low light. High temperature had a significant effect on the expression of XTH17, XTH18, XTH22, and EXPA20 (Table S4). While, only the expression level of EXPA20 was significantly improved by high temperature. Water potential also had a significant effect on the target genes, and only the expression of $X T H 17, X T H 18$, and $X T H 33$ was significantly induced by high water potential in different treatments $\left(\mathrm{L}_{h} \mathrm{~T}_{1} \mathrm{~W}_{\mathrm{h}}\right.$ vs $\mathrm{L}_{\mathrm{h}} \mathrm{T}_{1} \mathrm{~W}_{1}, \mathrm{~L}_{\mathrm{h}} \mathrm{T}_{\mathrm{h}} \mathrm{W}_{\mathrm{h}}$ vs $\mathrm{L}_{\mathrm{h}} \mathrm{T}_{\mathrm{h}} \mathrm{W}_{\mathrm{l}}, \mathrm{L}_{\mathrm{l}} \mathrm{T}_{1} \mathrm{~W}_{\mathrm{h}}$ vs $\mathrm{L}_{1} \mathrm{~T}_{1} \mathrm{~W}_{1}, \mathrm{~L}_{1} \mathrm{~T}_{\mathrm{h}} \mathrm{W}_{\mathrm{h}}$ vs $\mathrm{L}_{\mathrm{l}} \mathrm{T}_{\mathrm{h}} \mathrm{W}_{1}$ ). The results indicated that the three environmental factors regulated hypocotyl elongation by changing the expression level of different genes involved in affecting wall extensity.

\section{Wall volume and hypocotyl volume are coordinately regulated}

During hypocotyl elongation, the increases in the volume of the cell wall and hypocotyl were not always coordinated, which contributed to dynamic changes in wall thickness. Based on hypocotyl length and wall thickness, hypocotyl and wall volume were calculated (Table 4). The volume of the hypocotyl incrementally increased as it elongated, but the wall volume did not. At the final hypocotyl length, the hypocotyl volume increased by 1.92-, 1.29-, and 1.60-fold in response to low light, high temperature, and high water potential, respectively. The increases in the volume of the OE were 1.53-, 1.08-, and 1.18-fold, correspondingly; the increases in the volume of the IE were 1.68-, 1.05-, and 1.39-fold, correspondingly; and the increases in the volume of the $\mathrm{CO}$ were 1.34-, 1.06-, and 1.19-fold, correspondingly. The imbalance in the increases in the hypocotyl and cell wall volumes contributed to the dynamic changes in wall thickness under the combined effects of the three environmental factors. The analysis of wall volume further revealed that approximately $45 \%$ of the total wall volume was primarily present in the OE and approximately $30 \%$ in the IE. The other $25 \%$ presented in the CO. The results above were consistent with the epidermis-controlled organ elongation in a previous study (Kutschera \& Niklas, 2007).

\section{Discussion}

Hypocotyl elongation responding to the combined effects of multiple factors 
352 Light, temperature and water potential are often correlated under natural growth conditions and 353 regulate growth and development throughout the life of plants. Previous studies showed that the

354 regulation of light, temperature, and water potential on hypocotyl elongation was interdependent.

355 For example, the classical light response was temperature dependent: the reverse in the response

356 from the inhibition to the promotion of hypocotyl growth by light was induced by a shift in

357 temperature (Johansson et al., 2014). In addition, the promotion on hypocotyl elongation by high

358 temperature was light quality dependent and became stronger as F/FR decreased (Kurepin et al.,

359 2010). In the present study, we investigated the coordinated regulation of light intensity,

360

361

362

363

364

365

366

367

368

369

370

371

372

373

374

375

376

377

378

379

380

381

382

383

384

385

386

387

388

389

390

391 temperature, and water potential on hypocotyl elongation (Fig. 1). Low light, high temperature, and high water potential promoted hypocotyl elongation both in isolation and in coordination, which was similar to a previous study (Johansson et al., 2014; Kurepin et al., 2010; Wu et al., 2005). Under the combined effects of light intensity, temperature, and water potential, the elongation rate incrementally decreased. The rate was relatively quick at $2 \mathrm{~d}$, when the hypocotyl reached approximately $50 \%$ of its final length (Fig. 1). The elongation rate decreased by $80 \%$ when the $90 \%$ final hypocotyl length was reached at $5 \mathrm{~d}$. At $8 \mathrm{~d}$, the final hypocotyl length was reached, and elongation rate decreased. The gradual decrease in the rate contributed to the elongation kinetics of the hypocotyl.

\section{Contributions of cell elongation and division to hypocotyl growth}

Hypocotyl elongation resulted from cell elongation, cell division, or both, depending on species and growth conditions (Boron \& Vissenberg, 2014; Kutschera \& Niklas, 2013). Previous studies revealed that hypocotyl elongation in $A$. thaliana occurred primarily by cell elongation with almost no contribution from division (Gendreau et al., 1997). Cell division played a critical role in the hypocotyl elongation of lettuce, radish, and soybean at $0-2 \mathrm{~d}$ after germination, and cell elongation played a major role afterwards (Galli, 1988). Cell elongation and division were both observed during the hypocotyl elongation of H. annuus (Kutschera \& Niklas, 2013). A previous study showed that cucumber hypocotyl elongated in the absence of cell division when grown in dim light, and cell division appeared under high light (Lopez-Juez et al., 1995). In the present study, the contribution of cell elongation and division to hypocotyl growth in B. rapa was highly dependent on cell types and growth conditions, and cell division was observed only in the epidermis under low light.

Further study indicated that cell division was only active at the stage of embryogenesis, and cell division was confined to the meristem of the root and stem and the stomatal development region after seed germination in the epidermis of A. thaliana and B. napus (Barroco et al., 2005; Raz \& Koornneef, 2001). As the receptor of multiple environmental factors, phytochrome B (phyB) played a critical role both in regulating cell elongation in hypocotyl growth and cell division during stomatal development that accounted for the increase in cell layers in the epidermis of B. rapa hypocotyl (Fig. 2) (Casson et al., 2009; Wang \& Shang, 2018). Moreover, low light, high temperature, and high water potential significantly promoted cell elongation in hypocotyl by increasing auxin content, which is primarily biosynthesized by YUCCA8/9 in dicotyledonous plants (Sun et al., 2012; Zhao, 2010). The expression of YUCCA8/9 was induced 
392 by phytochrome interacting factor 4 (PIF4), which can be degraded after phosphorylation when

393

394

395

396

397

398

399

400

401

402

403

404

405

406

407

408

409

410

411

412

413

414

415

416

417

418

419

420

421

422

423

424

425

426

427

428

429

430

431

interacting with phyB in an activated state (Delker et al., 2014; Franklin et al., 2011). As the emerging hub of environmental signaling pathways in regulating hypocotyl elongation, the protein abundance and activity state of phyB are regulated by light intensity, temperature, and water potential. (Casal \& Questa, 2018; Legris et al., 2017; Wang \& Shang, 2018). In addition, phyB also regulated hypocotyl elongation by regulating the signaling of hormones, such as IAA and BR. PhyB could interact with auxin/indoleacetic acid (Aux/IAA) proteins to inhibit the signal transduction of IAA (Xu et al., 2018). PhyB also attenuated the positive influence of brassinolide (BR) on regulating hypocotyl elongation by repressing the accumulation of PIF4, which interacted with downstream responsive factors of BR, such as BZR1 and BES1 (Bai et al., 2012).

\section{Cell wall: the co-target of light, temperature, and water potential in regulating hypocotyl elongation}

Plant cells are surrounded by extensible walls, which allows for the turgor-mediated expansion in cell volume. Newly synthesized polymers should be incorporated into the expanding walls; otherwise, the wall would become thinner until it was broken by turgor pressure (Derbyshire et al., 2007a; Refregier et al., 2004). A previous study showed that changes in wall thickness were relatively complex and highly dependent on cell types, growth conditions, and developmental stages. Different phases of wall thickening, maintenance, and thinning were observed (Derbyshire et al., 2007a; Refregier et al., 2004; Wolf \& Greiner, 2012). In the present study, the thickness of the OE increased incrementally during hypocotyl elongation. However, the IE and $\mathrm{CO}$ displayed phases of becoming thicker, maintaining the thickness, or getting thinner, implying an imbalance of wall deposition and hypocotyl elongation. The results above were consistent with previous reports (Derbyshire et al., 2007a; Fujino \& Itoh, 1998; Refregier et al., 2004). Cell wall analysis has been performed in different species, including maize coleoptiles, peas internodes, and A. thaliana hypocotyls (Derbyshire et al., 2007a; Fujino \& Itoh, 1998). However, this is the first report on the dynamic changes of wall thickness in different cell types as the hypocotyl elongated in B. rapa.

The biosynthesis and deposition of the cell wall are regulated by multiple factors. For example, light intensity plays a key role in regulating plant growth by adjusting the deposition of cellulose, hemicellulose, and lignin (Le Gall et al., 2015). Constant or transitory high temperatures can induce a series of physiological and biochemical changes in plant growth by inducing an increase in hemicellulose deposition and a decrease in pectin accumulation (Lima et al., 2013; Suwa et al., 2010). Under water-deficit and salt stresses, cellulose and hemicellulose contents remained unchanged, but pectin content markedly increased (An et al., 2014; Muszyńska et al., 2014). In the present study, the contribution of the wall components to the dynamic changes in wall thickness was highly dependent on the light intensity, temperature, and water potential. Light intensity had significant effects on cellulose, hemicellulose, and pectin deposition, but high temperature and high water potential had significant effects on pectin content. Pectin is the most abundant component of the primary wall in eudicot plants and 
432 regulates hypocotyl growth in response to low light, high temperature, and high water potential 433 by influencing wall extensity (Wolf \& Greiner, 2012; Xiao et al., 2014; Xiao et al., 2017). The 434 gradients in pectin contributed to the gradient elongation rate of the hypocotyl, with higher rates 435 in the apex and lower rates in cells near the base (Goldberg et al., 1986; Phyo et al., 2017). The 436 results above indicated that the cell wall may be the target of multiple factors in regulating 437 hypocotyl elongation. Light intensity, temperature, and water potential regulated hypocotyl 438 elongation by affecting wall deposition, especially the deposition of pectin.

439 440

441

442

443

444

445

446

447

448

449

450

451

452

453

454

455

456

457

458

459

460

461

462

463

464

465

466

467

468

469

470

\section{Imbalance of wall deposition and hypocotyl elongation contributed to dynamic changes in wall thickness}

As the hypocotyl elongated, the volume of the hypocotyl and the cell wall both increased.

However, the increase in the volume of the cell wall did not keep pace with that of hypocotyl, so the increase in cell size was achieved by stretching the existing wall, and then wall thickness decreased (Table 4). At the final length, the hypocotyl was 1.93-fold longer under low light than under high light, but the thickness of the OE, IE, and CO was reduced by 0.19-, 0.35-, and 0.35fold, respectively. The increase in hypocotyl length induced by high temperature was 1.29-fold, while the decrease in the thickness of the OE, IE, and CO was 0.16-, 0.09-, and 0.14-fold, respectively. In addition, high water potential promoted hypocotyl elongation by 1.18 -fold, and the OE, IE, and CO decreased by $0.14-, 0.18$-, and 0.14 -fold, respectively. The results above indicated that the imbalance of hypocotyl elongation and wall deposition contributed to the changes in wall thickness. The changes in wall thickness could subsequently influenced hypocotyl elongation, and the elongation rates declined as wall thickness increased.

In the present study, we analyzed the combined effects of light intensity, temperature, and water potential on plant growth using hypocotyl as a model system. The interaction of these factors was particularly evident at the early stage of seedling growth, which indicated that more attention should be paid to temperature and water control in the early stage of seedling growth to prevent them from being leggy in the process of vegetable production and planting. In addition, this description of the dynamic changes in wall thickness provided a sound baseline for the identification of key stages of hypocotyl elongation and wall biosynthesis.

\section{Conclusions}

Light intensity, temperature and water potential regulated the hypocotyl growth of $B$. rapa both in isolation and combination. Low light, high temperature, and high water potential promoted hypocotyl growth by regulating cell elongation in a process that was tightly controlled by the cell wall. The thickness of OE, IE, and CO changed variously, namely, thickening-thinningthickening, thickening-thinning-maintaining, and thickening-maintaining-thinning, respectively. Further analysis revealed that the imbalance in wall deposition and hypocotyl elongation contributed to dynamic changes in wall thickness. Light intensity, temperature and water potential modulated cell wall deposition by regulating pectin biosynthesis. In conclusion, light intensity, temperature, and water potential regulated hypocotyl elongation of B. rapa by influencing wall deposition, especially the deposition of pectin. 


\section{Acknowledgements}

472 This work was supported by grants from the National Natural Science Foundation of China 473 (31172001), the China Agriculture Research System (CARS-25), the Special Fund for agro474 scientific research in the public Interest of China (201303014), and the Science and 475 Technological Innovation Program of Chinese Academy of Agricultural Sciences (CAAS476 ASTIP-IVFCAAS).

\section{References}

478

479

480

481

482

483

484

485

486

487

488

489

490

491

492

493

494

495

496

497

498

499

500

501

502

503

504

505

506

507

508

509

510

511

512

513

514

An P, Li X, Zheng Y, Matsuura A, Abe J, Eneji AE, Tanimoto E, and Inanaga S. 2014. Effects of $\mathrm{NaCl}$ on root growth and cell wall composition of two soya bean cultivars with contrasting salt tolerance. Journal of Agronomy and Crop Science 200:212-218. DOI $10.1111 / \mathrm{jac} .12060$.

Bai MY, Shang JX, Oh E, Fan M, Bai Y, Zentella R, Sun TP, Wang ZY. 2012. Brassinosteroid, gibberellin and phytochrome impinge on a common transcription module in Arabidopsis. Nature Cell Biology 14: 810-817. DOI 10.1038/ncb2546.

Barroco RM, Van Poucke K, Bergervoet JH, De Veylder L, Groot SP, Inze D, and Engler G. 2005. The role of the cell cycle machinery in resumption of postembryonic development. Plant Physiology 137:127-140. DOI 10.1104/pp.104.049361.

Bischoff V, Desprez T, Mouille G, Vernhettes S, Gonneau M, and Hofte H. 2011. Phytochrome regulation of cellulose synthesis in Arabidopsis. Current Biology 21:1822-1827. DOI 10.1016/j.cub.2011.09.026.

Boron AK, and Vissenberg K. 2014. The Arabidopsis thaliana hypocotyl, a model to identify and study control mechanisms of cellular expansion. Plant Cell Reports 33:697-706. DOI 10.1007/s00299-014-1591-x.

Casal JJ, and Questa JI. 2018. Light and temperature cues: multitasking receptors and transcriptional integrators. New Phytologist 217:1029-1034. DOI 10.1111/nph.14890.

Casson SA, Franklin KA, Gray JE, Grierson CS, Whitelam GC, and Hetherington AM. 2009. phytochrome B and PIF4 regulate stomatal development in response to light quantity. Current Biology 19:229-234. DOI 10.1016/j.cub.2008.12.046.

Cosgrove DJ. 2016. Plant cell wall extensibility: connecting plant cell growth with cell wall structure, mechanics, and the action of wall-modifying enzymes. Journal of Experimential Botany 67:463-476. DOI 10.1093/jxb/erv511.

Delker C, Sonntag L, James GV, Janitza P, Ibanez C, Ziermann H, Peterson T, Denk K, Mull S, Ziegler J, Davis SJ, Schneeberger K, and Quint M. 2014. The DET1-COP1-HY5 pathway constitutes a multipurpose signaling module regulating plant photomorphogenesis and thermomorphogenesis. Cell Reports 9:1983-1989. DOI 10.1016/j.celrep.2014.11.043.

Derbyshire P, Findlay K, McCann MC, and Roberts K. 2007a. Cell elongation in Arabidopsis hypocotyls involves dynamic changes in cell wall thickness. Journal of Experimential Botany 58:2079-2089. 10.1093/jxb/erm074.

Derbyshire P, McCann MC, and Roberts K. 2007b. Restricted cell elongation in Arabidopsis hypocotyls is associated with a reduced average pectin esterification level. BMC Plant Biology 7:31. DOI 10.1186/1471-2229-7-31.

Devlin PF, Somers DE, Quail PH, and Whitelam GC. 1997. The Brassica rapa elongated internode (EIN) gene encodes phytochrome B. Plant Molecular Biology 34:537-547. 
515 Dewitte W, Murray JA. 2003. The plant cell cycle. Annual Review of Plant Biology 54:235-264.

516

517

518

519

520

521

522

523

524

525

526

527

528

529

530

531

532

533

534

535

536

537

538

539

540

541

542

543

544

545

546

547

548

549

550

551

552

553

554

555

556

557

558

559

560 doi:10.1146/annurev.arplant.54.031902.134836.

Franklin KA, Lee SH, Patel D, Kumar SV, Spartz AK, Gu C, Ye S, Yu P, Breen G, Cohen JD, Wigge PA, and Gray WM. 2011. Phytochrome-interacting factor 4 (PIF4) regulates auxin biosynthesis at high temperature. Proceedings of National Academy of Sciences of the United States of America 108:20231-20235. DOI 10.1073/pnas.1110682108.

Fujino T, and Itoh T. 1998. Changes in pectin structure during epidermal cell elongation in Pea (Pisum sativum) and its implications for cell wall architecture. Plant Cell Physiology 39:1315-1323. DOI 10.1093/oxfordjournals.pcp.a029336.

Galli MG. 1988. The role of DNA synthesis during hypocotyl elongation in light and dark. Annals of Botany 62:287-294. DOI 10.1093/oxfordjournals.pcp.a029336.

Gendreau E, Traas J, Desnos T, Grandjean O, Caboche M, and Höfte H. 1997. Cellular basis of hypocotyl growth in Arabidopsis thaliana. Plant Physiology 114:295-305. DOI 10.1104/pp.114.1.295.

Goldberg R, Morvan C, Roland JC.1986. Composition, properties and localisation of pectins in young and mature cells of the mung bean hypocotyl. Plant Cell Physiology 27: 417-429. DOI 10.1093/oxfordjournals.pcp.a077118.

Hersch M, Lorrain S, de Wit M, Trevisan M, Ljung K, Bergmann S, and Fankhauser C. 2014. Light intensity modulates the regulatory network of the shade avoidance response in Arabidopsis. Proceedings of National Academy of Sciences of the United States of America 111:6515-6520. DOI 10.1073/pnas.1320355111.

Iraki NM, Bressan RA, Hasegawa PM, and Carpita NC. 1989. Alteration of the physical and chemical structure of the primary cell wall of growth-limited plant cells adapted to osmotic stress. Plant Physiology 91:39-47. DOI 10.1104/pp.91.1.39.

Ivakov A, Flis A, Apelt F, Funfgeld M, Scherer U, Stitt M, Kragler F, Vissenberg K, Persson S, and Suslov D. 2017. Cellulose synthesis and cell expansion are regulated by different mechanisms in growing Arabidopsis hypocotyls. Plant Cell 29:1305-1315. DOI 10.1105/tpc. 16.00782 .

Johansson H, Jones HJ, Foreman J, Hemsted JR, Stewart K, Grima R, and Halliday KJ. 2014. Arabidopsis cell expansion is controlled by a photothermal switch. Nature Communications 5:4848. DOI 10.1038/ncomms5848.

Joubès J, Chevalier C, Dudits D, Heberlebors E, Inzé D, Umeda M, Renaudin JP. 2000. CDKrelated protein kinases in plants. Plant Molecular Bology 43 (5-6):607-620. DOI 10.1023/A:1006470301554.

Kurepin LV, Walton LJ, Pharis RP, Neil Emery RJ, and Reid DM. 2010. Interactions of temperature and light quality on phytohormone-mediated elongation of Helianthus annuus hypocotyls. Plant Growth Regulation 64:147-154. DOI 10.1007/s10725-0109549-7.

Kutschera U, and Niklas KJ. 2007. The epidermal-growth-control theory of stem elongation: an old and a new perspective. Journal of Plant Physiology 164:1395-1409. DOI 10.1016/j.jplph.2007.08.002.

Kutschera U, and Niklas KJ. 2013. Cell division and turgor-driven stem elongation in juvenile plants: a synthesis. Plant Science 207:45-56. DOI 10.1016/j.plantsci.2013.02.004

Labavitch JM, and Ray PM. 1974. Relationship between promotion of xyloglucan metabolism and induction of elongation by indoleacetic acid. Plant Physiology 54:499-502. DOI 10.1104/pp.54.4.499. 
561

562

563

564

565

566

567

568

569

570

571

572

573

574

575

576

577

578

579

580

581

582

583

584

585

586

587

588

589

590

591

592

593

594

595

596

597

598

599

600

601

602

603

604

605

Le Gall H, Philippe F, Domon JM, Gillet F, Pelloux J, and Rayon C. 2015. Cell wall metabolism in response to abiotic stress. Plants (Basel) 4:112-166. DOI 10.3390/plants4010112.

Legris M, Nieto C, Sellaro R, Prat S, and Casal JJ. 2017. Perception and signalling of light and temperature cues in plants. Plant Journal 90:683-697. DOI 10.1111/tpj.13467.

Lima RB, dos Santos TB, Vieira LG, Ferrarese Mde L, Ferrarese-Filho O, Donatti L, Boeger MR, and Petkowicz CL. 2013. Heat stress causes alterations in the cell-wall polymers and anatomy of coffee leaves (Coffea arabica L.). Carbohydrate Polymers 93:135-143. DOI 10.1016/j.carbpol.2012.05.015.

Lopez-Juez E, Kobayashi M, Sakurai A, Kamiya Y, and Kendrick RE. 1995. Phytochrome, gibberellins, and hypocotyl growth (A Study Using the Cucumber (Cucumis sativus L.) long hypocotyl Mutant). Plant Physiology 107:131. DOI 10.1104/pp.107.1.131.

Lorenzo CD, Sanchez-Lamas M, Antonietti MS, and Cerdan PD. 2016. Emerging hubs in plant light and temperature signaling. Photochemistry and Photobiology 92:3-13. DOI 10.1111/php.12535.

Muszyńska A, Jarocka K, and Kurczynska EU. 2014. Plasma membrane and cell wall properties of an aspen hybrid (Populus tremula $\times$ tremuloides) parenchyma cells under the influence of salt stress. Acta Physiologiae Plantarum 36:1155-1165. DOI 10.1007/s11738-0141490-3.

Paque S, Mouille G, Grandont L, Alabadí D, Gaertner C, Goyallon A, Muller P, Primard-Brisset C, Sormani R, Blázquez MA, and Perrot-Rechenmann C. 2014. AUXIN BINDING PROTEIN1 links cell wall remodeling, auxin signaling, and cell expansion in Arabidopsis. The Plant cell 26: 280-195.DOI 10.1105/tpc.113.120048.

Patel D, and Franklin KA. 2014. Temperature-regulation of plant architecture. Plant Signaling \& Behavior 4:577-579. DOI 10.4161/psb.4.7.8849.

Pereyra CM, Ramella NA, Pereyra MA, Barassi CA, and Creus CM. 2010. Changes in cucumber hypocotyl cell wall dynamics caused by Azospirillum brasilense inoculation. Plant Physiology Biochemistry 48:62-69. DOI 10.1016/j.plaphy.2009.10.001.

Phyo P, Wang T, Kiemle SN, O'Neill H, Pingali SV, Hong M, Cosgrove DJ. 2017. Gradients in wall mechanics and polysaccharides along growing inflorescence stems. Plant Physiology 175:1593-1607. DOI 10.1104/pp.17.01270.

Procko C, Crenshaw CM, Ljung K, Noel JP, and Chory J. 2014. Cotyledon-generated auxin is required for shade-induced hypocotyl growth in Brassica rapa. Plant Physiology 165:1285-1301. DOI 10.1104/pp.114.241844.

Qi J, Yu S, Zhang F, Shen X, Zhao X, Yu Y, and Zhang D. 2010. Reference gene selection for real-time quantitative polymerase chain reaction of mRNA transcript levels in Chinese Cabbage (Brassica rapa L. ssp. pekinensis). Plant Molecular Biology Reporter 28:597604. DOI 10.1007/s11105-010-0185-1.

Raz V, and Koornneef M. 2001. Cell division activity during apical hook development. Plant Physiology 125:219-226. DOI 10.1007/s003740050007.

Refregier G, Pelletier S, Jaillard D, and Hofte H. 2004. Interaction between wall deposition and cell elongation in dark-grown hypocotyl cells in Arabidopsis. Plant Physiology 135:959968. DOI 10.1104/pp.104.038711.

Sasidharan R, Voesenek LACJ, and Pierik R. 2011. Cell wall modifying proteins mediate plant acclimatization to biotic and abiotic Stresses. Critical Reviews in Plant Sciences 30:548562. DOI 10.1080/07352689.2011.615706.

Peer) reviewing PDF | (2019:08:40056:3:0:NEW 27 Mar 2020) 
606 Scheres B, Wolkenfelt H, Willemsen V, Terlouw M, Lawson E, Dean C, and Weisbeek P. 1994.

607

608

609

610

611

612

613

614

615

616

617

618

619

620

621

622

623

624

625

626

627

628

629

630

631

632

633

634

635

636

637

638

639

640

641

642

643

644

645

646

647

648

649

650

651
Embryonic origin of the Arabidopsis primary root and root meristem initials. Development 120:2475-2487. DOI 10.1002/cyto.990170113.

Schmittgen TD, and Livak KJ. 2008. Analyzing real-time PCR data by the comparative CT method. Nature Protocols 3:1101-1108. DOI 10.1038/nprot.2008.73.

Stark SM. 1950. Determination of Pectic Substances in Cotton. Analytical Chemistry 22:11581160. DOI 10.1021/ac60045a017.

Sun J, Qi L, Li Y, Chu J, and Li C. 2012. PIF4-mediated activation of YUCCA8 expression integrates temperature into the auxin pathway in regulating Arabidopsis hypocotyl growth. PLoS genetics 8:e1002594. DOI 10.1371/journal.pgen.1002594.

Suwa R, Hakata H, Hara H, El-Shemy HA, Adu-Gyamfi JJ, Nguyen NT, Kanai S, Lightfoot DA, Mohapatra PK, and Fujita K. 2010. High temperature effects on photosynthate partitioning and sugar metabolism during ear expansion in maize (Zea mays L.) genotypes. Plant Physiology Biochemistry 48:124-130. DOI 10.1016/j.plaphy.2009.12.010.

Updegraff DM. 1969. Semimicro determination of cellulose in biological materials. Analytical Biochemistry 32:420. DOI 10.1016/S0003-2697(69)80009-6.

Voxeur A, and Hofte H. 2016. Cell wall integrity signaling in plants: "To grow or not to grow that's the question". Glycobiology 26:950-960. DOI 10.1093/glycob/cww029.

Wang H, and Shang Q. 2018. Identification and functional analysis of proteins in response to light intensity, temperature and water potential in Brassica rapa hypocotyl. Physiology Plantarum. DOI 10.1111/ppl.12865.

Wilkinson S, and Davies WJ. 2010. Drought, ozone, ABA and ethylene: new insights from cell to plant to community. Plant Cell Environment 33:510-525. DOI 10.1111/j.13653040.2009.02052.x.

Wolf S, and Greiner S. 2012. Growth control by cell wall pectins. Protoplasma 249 Suppl 2:S169-175. DOI 10.1007/s00709-011-0371-5.

Wu Y, Jeong BR, Fry SC, and Boyer JS. 2005. Change in XET activities, cell wall extensibility and hypocotyl elongation of soybean seedlings at low water potential. Planta 220:593601. DOI 10.1007/s00425-004-1369-4.

Xiao C, Barnes WJ, Zamil MS, Yi H, Puri VM, and Anderson CT. 2017. Activation tagging of Arabidopsis POLYGALACTURONASE INVOLVED IN EXPANSION2 promotes hypocotyl elongation, leaf expansion, stem lignification, mechanical stiffening, and lodging. Plant Journal 89:1159-1173. DOI 10.1111/tpj.13453.

Xiao C, Somerville C, and Anderson CT. 2014. POLYGALACTURONASE INVOLVED IN EXPANSION1 functions in cell elongation and flower development in Arabidopsis. Plant Cell 26:1018-1035. DOI 10.1105/tpc.114.123968.

Xu F, He S, Zhang J, Mao Z, Wang W, Li T, Hua J, Du S, Xu P, Li L, Lian H, Yang HQ. 2017. Photoactivated CRY1 and phyB interact directly with AUX/IAA proteins to inhibit auxin signaling in Arabidopsis. Molecular Plant 11: 523-541. DOI 10.1016/j.molp.2017.12.003.

Zhao Y. 2010. Auxin biosynthesis and its role in plant development. Annual Review of Plant Biology 61:49-64. DOI 10.1146/annurev-arplant-042809-112308.

Zhong H, and Lauchli A. 1993. Changes of cell wall composition and polymer size in primary roots of cotton seedlings under high salinity. Journal of Experimental Botany 44:773778. DOI 10.1093/jxb/44.4.773. 


\section{Figure 1}

Figure 1 Hypocotyl elongation dynamics in $B$. rapa responding to light intensity, temperature and water potential.

(A-H) Photographs of $B$. rapa seedling under different growth conditions at $8 \mathrm{~d}$. Scale bars $=$ $1 \mathrm{~cm}$. (I) Dynamic curve of hypocotyl elongation. Values in the pictures are means $\pm S E(n=$ $30)$. Arrows indicate times $(0,2,5$, and $8 \mathrm{~d})$ at which hypocotyls are used to analyze wall thickness in further. Abbreviations: $L$ represents light intensity; T represents temperature; $W$ represents water potential; h represents high; I represents low. 

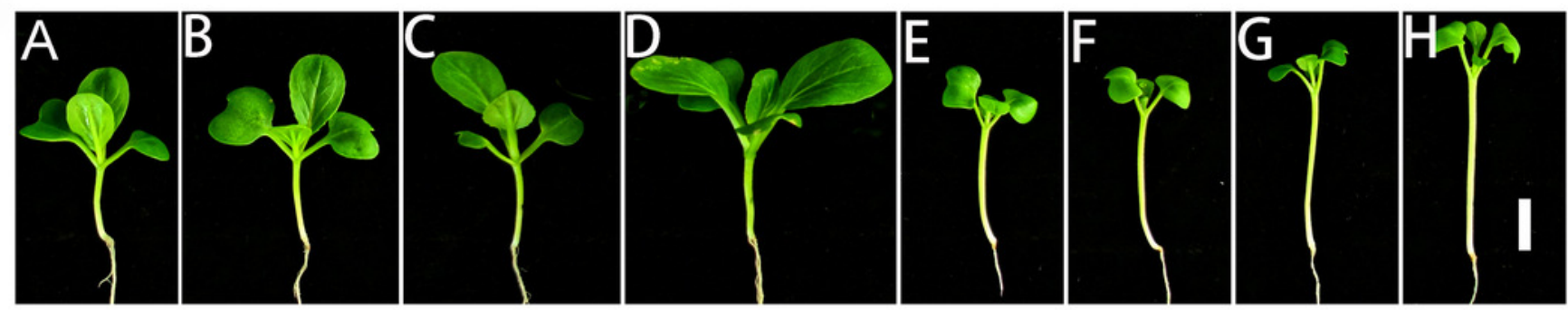

$L_{h} T_{1} W_{1} \quad L_{h} T_{1} W_{h}$

$\mathrm{L}_{\mathrm{h}} \mathrm{T}_{\mathrm{h}} \mathrm{W}_{\mathrm{l}}$

$L_{h} T_{h} W_{h}$

$\mathrm{L}_{\mathrm{I}} \mathrm{T}_{\mathrm{I}} \mathrm{W}_{\mathrm{I}}$

$L_{1} T_{1} W_{h} \quad L_{1} T_{h} W_{1} L_{1} T_{h} W_{h}$

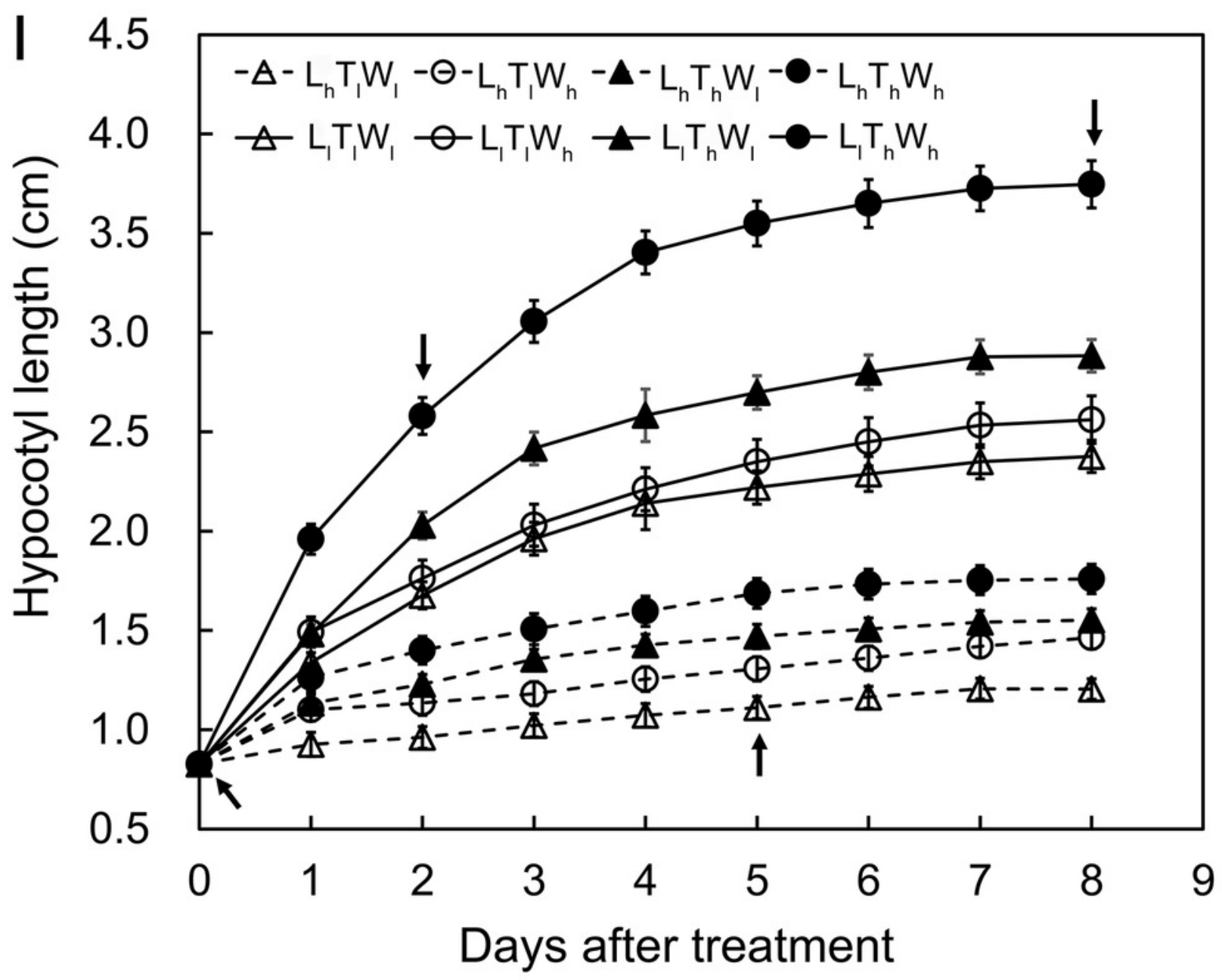




\section{Figure 2}

Figure 2 Pictures of paraffin section in hypocotyl of $B$. rapa treated for $8 \mathrm{~d}$.

(A-H) Paraffin sections of $B$. rapa seedling grown under $L_{h} T_{1} W_{1}, L_{h} T_{1} W_{h}, L_{h} T_{h} W_{1}, L_{h} T_{h} W_{h}, L_{1} T_{1} W_{1}$, $L_{1} T_{1} W_{h}, L_{1} T_{h} W_{l}, L_{l} T_{h} W_{h}$. Scale bars $=100 \mu m$. Abbreviations: $L$ represents light intensity; $T$ represents temperature; W represents water potential; h represents high; I represents low; EP represents epidermis; CT represents cortex.

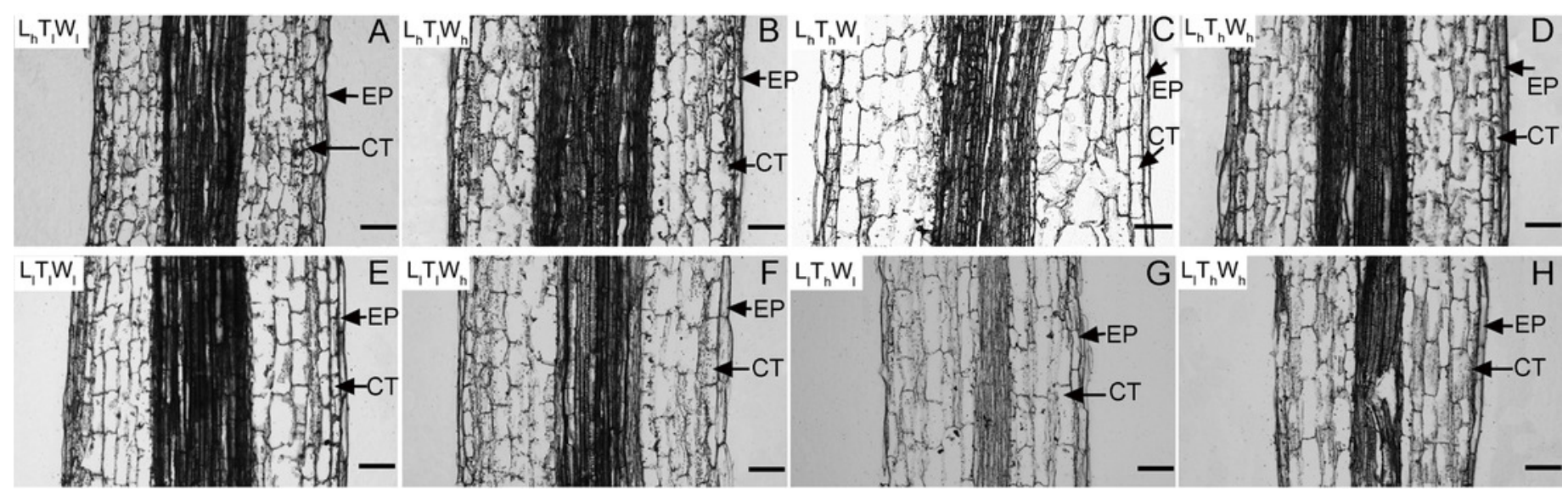




\section{Figure 3}

Figure 3 Transmission electron photographs of hypocotyl at the mid-point in $B$. rapa hypocotyl grown for $8 \mathrm{~d}$.

(A-H) The micrographs of OE at the mid-point in B. rapa hypocotyl. (I-P) The micrographs of the cell corner at the mid-point in B. rapa hypocotyl. Arrows in the picture indicate the walls used for thickness measurement. Abbreviations: L, light intensity; T, temperature; W, water potential; h, high; I, low; OE, outer epidermal wall; IE, inner epidermal wall; CO, cortical wall. Scale bar $=2 \mu \mathrm{m}$.

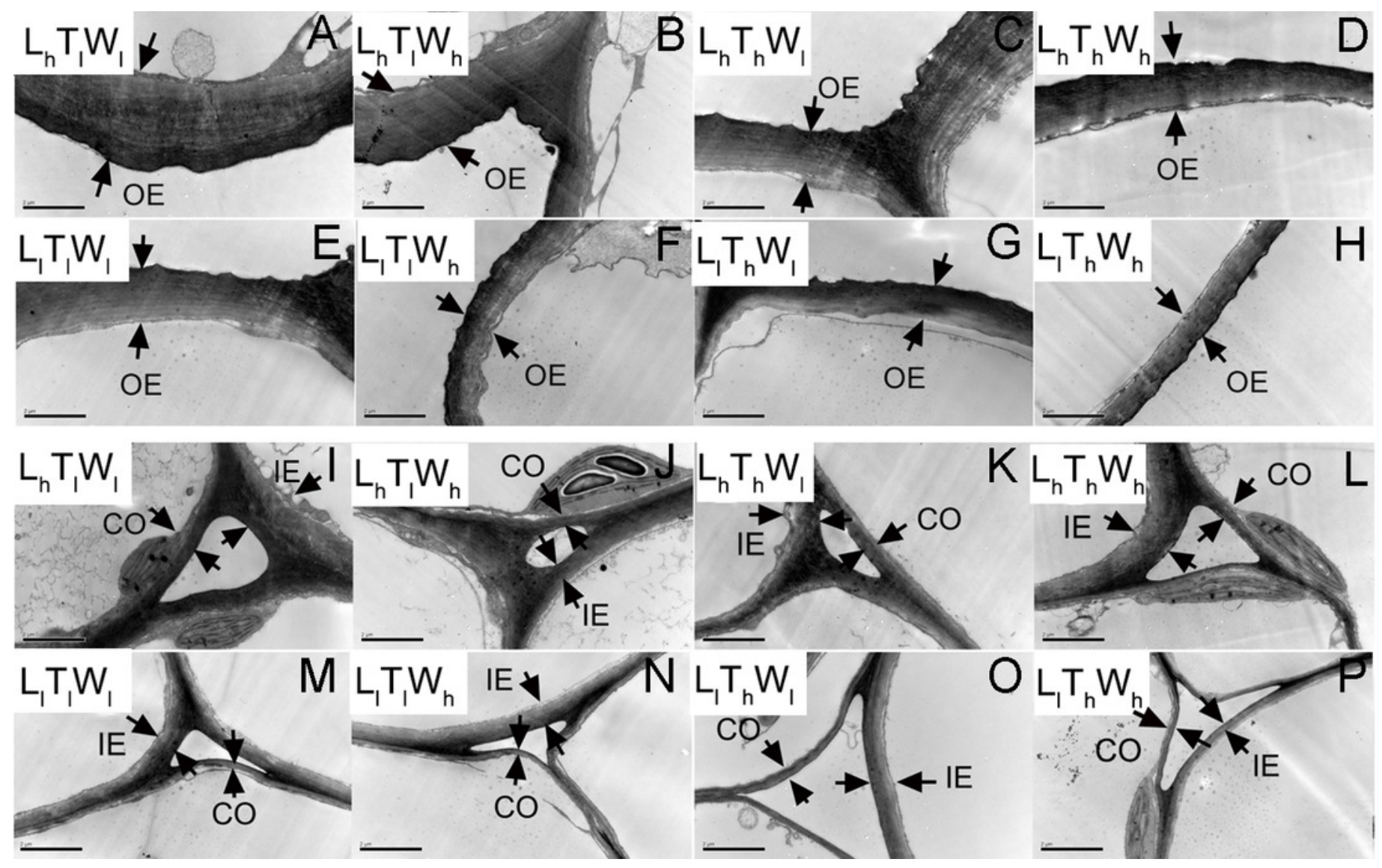




\section{Figure 4}

Figure 4 Cell wall thickness of hypocotyls under the combined effects of light intensity, temperature, and water potential at different developmental stages.

(A) Dynamic change in thickness of outer epidermal wall. (B) Dynamic change in thickness of inner epidermal wall. (C) Thickness of cortical wall. Values in the figure are means \pm SE $(n=$ 15). Different letters ( $a, b, c, d, e$, and f) are used to indicate significance among treatments $(P<0.05 ;$ Duncan's multiple range test). 

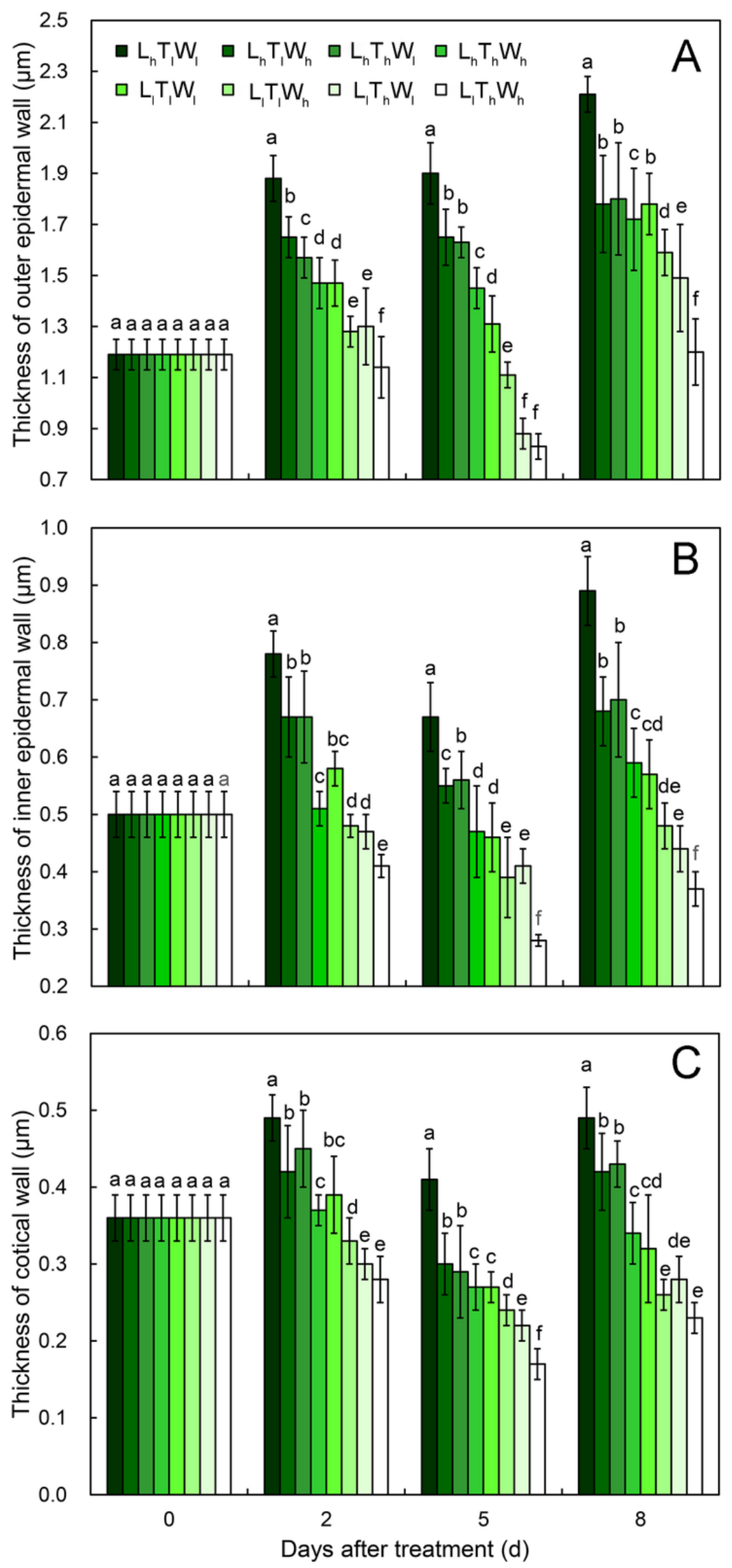


\section{Table $\mathbf{1}$ (on next page)}

Table 1 Growth conditions of $B$. rapa seedlings.

Data in the table represent the means $\pm \mathrm{SE}$. Abbreviations: L, light intensity; $T$, temperature; W, water potential; h, high; I, low. 


\begin{tabular}{llll}
\hline Growth condition & $\begin{array}{l}\text { Light intensity } \\
\left(\mu \mathrm{mol} \mathrm{m} \mathrm{m}^{-1}\right)\end{array}$ & Temperature $\left({ }^{\circ} \mathrm{C}\right)$ & Water potential (MPa) \\
\hline $\mathrm{L}_{\mathrm{h}} \mathrm{T}_{1} \mathrm{~W}_{1}$ & $250 \pm 10$ & $21 \pm 1$ & $-0.15 \pm 0.01$ \\
$\mathrm{~L}_{\mathrm{h}} \mathrm{T}_{1} \mathrm{~W}_{\mathrm{h}}$ & $250 \pm 10$ & $21 \pm 1$ & $-0.05 \pm 0.01$ \\
$\mathrm{~L}_{\mathrm{h}} \mathrm{T}_{\mathrm{h}} \mathrm{W}_{1}$ & $250 \pm 10$ & $29 \pm 1$ & $-0.15 \pm 0.01$ \\
$\mathrm{~L}_{\mathrm{h}} \mathrm{T}_{\mathrm{h}} \mathrm{W}_{\mathrm{h}}$ & $250 \pm 10$ & $29 \pm 1$ & $-0.05 \pm 0.01$ \\
$\mathrm{~L}_{1} \mathrm{~T}_{1} \mathrm{~W}_{1}$ & $50 \pm 10$ & $21 \pm 1$ & $-0.15 \pm 0.01$ \\
$\mathrm{~L}_{1} \mathrm{~T}_{1} \mathrm{~W}_{\mathrm{h}}$ & $50 \pm 10$ & $21 \pm 1$ & $-0.05 \pm 0.01$ \\
$\mathrm{~L}_{1} \mathrm{~T}_{\mathrm{h}} \mathrm{W}_{1}$ & $50 \pm 10$ & $29 \pm 1$ & $-0.15 \pm 0.01$ \\
$\mathrm{~L}_{\mathrm{l}} \mathrm{T}_{\mathrm{h}} \mathrm{W}_{\mathrm{h}}$ & $50 \pm 10$ & $29 \pm 1$ & $-0.05 \pm 0.01$ \\
\hline
\end{tabular}

1 


\section{Table 2 (on next page)}

Table 2 The combined effects of light intensity, temperature, and water potential on cell length and cell number in $B$. rapa hypocotyl.

Values in the table are means $\pm S E(n=15)$. Different letters $(a, b, c, d, e$, and f) are used to indicate significance among treatments ( $P<0.05$; Duncan's multiple range test). Abbreviations: L, light intensity; T, temperature; $W$, water potential; $h$, high; I, low. 


\begin{tabular}{ccccc}
\hline \multirow{2}{*}{ Treatment } & \multicolumn{2}{c}{ Epidermis } & \multicolumn{2}{c}{ Cortex } \\
\cline { 2 - 5 } & Cell Length $(\mu \mathrm{m})$ & Cell Number & Cell Length $(\mu \mathrm{m})$ & Cell Number \\
\hline $\mathrm{L}_{\mathrm{h}} \mathrm{T}_{1} \mathrm{~W}_{1}$ & $86.94 \pm 2.32 \mathrm{f}$ & $127.88 \pm 1.32 \mathrm{~d}$ & $79.48 \pm 8.67 \mathrm{f}$ & $139.88 \pm 1.23 \mathrm{de}$ \\
$\mathrm{L}_{\mathrm{h}} \mathrm{T}_{\mathrm{l}} \mathrm{W}_{\mathrm{h}}$ & $93.51 \pm 3.48 \mathrm{e}$ & $139.84 \pm 4.37 \mathrm{e}$ & $94.72 \pm 5.15 \mathrm{e}$ & $138.58 \pm 6.90 \mathrm{e}$ \\
$\mathrm{L}_{\mathrm{h}} \mathrm{T}_{\mathrm{h}} \mathrm{W}_{\mathrm{l}}$ & $97.20 \pm 5.53 \mathrm{e}$ & $151.25 \pm 8.15 \mathrm{c}$ & $94.23 \pm 4.54 \mathrm{e}$ & $156.04 \pm 7.08 \mathrm{bc}$ \\
$\mathrm{L}_{\mathrm{h}} \mathrm{T}_{\mathrm{h}} \mathrm{W}_{\mathrm{h}}$ & $106.10 \pm 4.16 \mathrm{~d}$ & $158.97 \pm 5.18 \mathrm{c}$ & $110.55 \pm 8.41 \mathrm{~d}$ & $153.93 \pm 10.69 \mathrm{~cd}$ \\
$\mathrm{~L}_{\mathrm{l}} \mathrm{T}_{\mathrm{l}} \mathrm{W}_{1}$ & $108.51 \pm 7.39 \mathrm{~d}$ & $195.49 \pm 2.45 \mathrm{~b}$ & $129.00 \pm 3.88 \mathrm{c}$ & $164.38 \pm 3.27 \mathrm{bc}$ \\
$\mathrm{L}_{\mathrm{l}} \mathrm{T}_{1} \mathrm{~W}_{\mathrm{h}}$ & $120.81 \pm 4.72 \mathrm{c}$ & $194.79 \pm 3.69 \mathrm{~b}$ & $150.63 \pm 10.20 \mathrm{~b}$ & $156.07 \pm 8.66 \mathrm{bc}$ \\
$\mathrm{L}_{\mathrm{l}} \mathrm{T}_{\mathrm{h}} \mathrm{W}_{1}$ & $129.12 \pm 3.17 \mathrm{~b}$ & $209.16 \pm 3.63 \mathrm{a}$ & $158.88 \pm 6.02 \mathrm{~b}$ & $169.95 \pm 4.58 \mathrm{ab}$ \\
$\mathrm{L}_{\mathrm{l}} \mathrm{T}_{\mathrm{h}} \mathrm{W}_{\mathrm{h}}$ & $182.40 \pm 11.47 \mathrm{a}$ & $189.14 \pm 2.95 \mathrm{~b}$ & $190.28 \pm 6.22 \mathrm{a}$ & $181.48 \pm 4.22 \mathrm{a}$ \\
\hline
\end{tabular}

1 


\section{Table 3 (on next page)}

Table 3 Cell wall mass and component contents under the influence of light intensity, temperature and water potential.

Data in the table represent the means $\pm \mathrm{SE}$. The letters $(a, b, c, d, e$, and f) indicate significance among treatments ( $P<0.05$; Duncan's multiple range test). Abbreviations: $L$, light intensity; $T$, temperature; $W$, water potential; $h$, high; I, low. 


\begin{tabular}{|c|c|c|c|c|c|c|c|c|}
\hline Content (mg g FW'-1) & $\mathrm{L}_{\mathrm{h}} \mathrm{T}_{1} \mathrm{~W}_{1}$ & $\mathrm{~L}_{\mathrm{h}} \mathrm{T}_{1} \mathrm{~W}_{\mathrm{h}}$ & $\mathrm{L}_{\mathrm{h}} \mathrm{T}_{\mathrm{h}} \mathrm{W}_{1}$ & $\mathrm{~L}_{\mathrm{h}} \mathrm{T}_{\mathrm{h}} \mathrm{W}_{\mathrm{h}}$ & $\mathrm{L}_{1} \mathrm{~T}_{1} \mathrm{~W}_{1}$ & $\mathrm{~L}_{1} \mathrm{~T}_{1} \mathrm{~W}_{\mathrm{h}}$ & $\mathrm{L}_{1} \mathrm{~T}_{\mathrm{h}} \mathrm{W}_{1}$ & $\mathrm{~L}_{1} \mathrm{~T}_{\mathrm{h}} \mathrm{W}_{\mathrm{h}}$ \\
\hline Wall mass & $47.54 \pm 2.03 \mathrm{a}$ & $43.82 \pm 1.10 \mathrm{~b}$ & $43.23 \pm 1.20 \mathrm{~b}$ & $36.78 \pm 1.45 \mathrm{c}$ & $27.09 \pm 0.90 \mathrm{~d}$ & $23.08 \pm 0.47 \mathrm{e}$ & $22.42 \pm 1.02 \mathrm{e}$ & $19.69 \pm 0.75 \mathrm{f}$ \\
\hline Cellulose & $11.12 \pm 0.26 \mathrm{ab}$ & $11.93 \pm 0.83 \mathrm{a}$ & $10.65 \pm 0.93 \mathrm{~b}$ & $10.56 \pm 0.79 \mathrm{~b}$ & $8.29 \pm 0.60 \mathrm{c}$ & $5.69 \pm 0.34 \mathrm{e}$ & $6.23 \pm 0.40 \mathrm{~d}$ & $4.94 \pm 0.42 \mathrm{f}$ \\
\hline Hemicellulose & $1.34 \pm 0.27 \mathrm{a}$ & $1.26 \pm 0.35 \mathrm{~b}$ & $1.33 \pm 0.11 \mathrm{a}$ & $1.21 \pm 0.15 b$ & $0.89 \pm 0.22 \mathrm{c}$ & $0.75 \pm 0.17 \mathrm{~d}$ & $0.77 \pm 0.17 \mathrm{~d}$ & $0.62 \pm 0.08 \mathrm{e}$ \\
\hline Pectin & $4.10 \pm 0.45 \mathrm{a}$ & $4.03 \pm 0.26 \mathrm{a}$ & $3.81 \pm 0.34 \mathrm{~b}$ & $3.01 \pm 0.17 \mathrm{c}$ & $2.52 \pm 0.23 \mathrm{~d}$ & $2.07 \pm 0.34 \mathrm{e}$ & $2.22 \pm 0.35 \mathrm{e}$ & $1.77 \pm 0.38 \mathrm{f}$ \\
\hline
\end{tabular}




\section{Table 4 (on next page)}

Table 4 Relationship analysis about the increase of cell wall volume and hypocotyl elongation.

Data in the table represent the means $\pm \mathrm{SE}$. Lowercase letters represent significance among treatments ( $P<0.05$; Duncan's multiple range test). Abbreviations: HY represents hypocotyl; OE represents outer epidermal wall; IE represents inner epidermal wall; CO represents cortical wall; TCW represents total cell wall; $L$ represents light intensity; $T$ represents temperature; W represents water potential; h represents high; I represents low. 


\begin{tabular}{cccccccc}
\hline \multirow{2}{*}{ Condition } & \multicolumn{9}{c}{ Volume $\left(\mathrm{mm}^{3}\right)$} \\
\cline { 2 - 8 } & HY & OE & IE & CO & TCW & EP & CO \\
\hline $\mathrm{L}_{\mathrm{h}} \mathrm{T}_{1} \mathrm{~W}_{1}$ & $4.799 \mathrm{f}$ & $0.060 \mathrm{~g}$ & $0.030 \mathrm{~h}$ & $0.038 \mathrm{c}$ & $0.128 \mathrm{~g}$ & $225.41 \mathrm{~b}$ & $227.49 \mathrm{a}$ \\
$\mathrm{L}_{\mathrm{h}} \mathrm{T}_{1} \mathrm{~W}_{\mathrm{h}}$ & $6.237 \mathrm{e}$ & $0.060 \mathrm{~g}$ & $0.039 \mathrm{f}$ & $0.035 \mathrm{~d}$ & $0.134 \mathrm{f}$ & $198.98 \mathrm{c}$ & $166.78 \mathrm{c}$ \\
$\mathrm{L}_{\mathrm{h}} \mathrm{T}_{\mathrm{h}} \mathrm{W}_{\mathrm{l}}$ & $6.540 \mathrm{e}$ & $0.064 \mathrm{f}$ & $0.035 \mathrm{~g}$ & $0.039 \mathrm{c}$ & $0.138 \mathrm{f}$ & $200.62 \mathrm{c}$ & $197.53 \mathrm{~b}$ \\
$\mathrm{~L}_{\mathrm{h}} \mathrm{T}_{\mathrm{h}} \mathrm{W}_{\mathrm{h}}$ & $8.608 \mathrm{~d}$ & $0.075 \mathrm{e}$ & $0.040 \mathrm{e}$ & $0.037 \mathrm{~cd}$ & $0.152 \mathrm{e}$ & $176.32 \mathrm{~d}$ & $160.26 \mathrm{c}$ \\
$\mathrm{L}_{\mathrm{l}} \mathrm{T}_{1} \mathrm{~W}_{1}$ & $8.520 \mathrm{~d}$ & $0.090 \mathrm{c}$ & $0.052 \mathrm{c}$ & $0.047 \mathrm{~b}$ & $0.188 \mathrm{c}$ & $262.45 \mathrm{a}$ & $130.95 \mathrm{~d}$ \\
$\mathrm{~L}_{\mathrm{l}} \mathrm{T}_{1} \mathrm{~W}_{\mathrm{h}}$ & $14.135 \mathrm{~b}$ & $0.107 \mathrm{~b}$ & $0.068 \mathrm{~b}$ & $0.048 \mathrm{~b}$ & $0.224 \mathrm{~b}$ & $198.66 \mathrm{c}$ & $126.60 \mathrm{~d}$ \\
$\mathrm{~L}_{\mathrm{l}} \mathrm{T}_{\mathrm{h}} \mathrm{W}_{1}$ & $9.111 \mathrm{c}$ & $0.085 \mathrm{~d}$ & $0.044 \mathrm{~d}$ & $0.036 \mathrm{~d}$ & $0.165 \mathrm{~d}$ & $139.87 \mathrm{f}$ & $79.98 \mathrm{f}$ \\
$\mathrm{L}_{\mathrm{l}} \mathrm{T}_{\mathrm{h}} \mathrm{W}_{\mathrm{h}}$ & $19.202 \mathrm{a}$ & $0.114 \mathrm{a}$ & $0.079 \mathrm{a}$ & $0.067 \mathrm{a}$ & $0.259 \mathrm{a}$ & $157.62 \mathrm{e}$ & $94.99 \mathrm{e}$ \\
\hline
\end{tabular}

1 